\title{
Atmospheric ammonia and particulate inorganic nitrogen over the United States
}

\author{
C. L. Heald ${ }^{1}$, J. L. Collett Jr. ${ }^{2}$, T. Lee ${ }^{2}$, K. B. Benedict ${ }^{2}$, F. M. Schwandner ${ }^{2,}{ }^{*}$, Y. Li ${ }^{2}$, L. Clarisse ${ }^{3}$, D. R. Hurtmans ${ }^{3}$, \\ M. Van Damme ${ }^{3}$, C. Clerbaux ${ }^{3,4}$, P.-F. Coheur ${ }^{3}$, S. Philip ${ }^{5}$, R. V. Martin ${ }^{5}$, and H. O. T. Pye \\ ${ }^{1}$ Department of Civil and Environmental Engineering and Department of Earth, Atmospheric and Planetary Sciences, MIT, \\ Cambridge, MA, USA \\ ${ }^{2}$ Department of Atmospheric Science, Colorado State University, Fort Collins, CO, USA \\ ${ }^{3}$ Spectroscopie de l'Atmosphère, Service de Chimie Quantique et Photophysique, Université Libre de Bruxelles, \\ Brussels, Belgium \\ ${ }^{4}$ UPMC Univ. Paris 06, Université Versailles St-Quentin, CNRS/INSU, LATMOS-IPSL, Paris, France \\ ${ }^{5}$ Department of Physics and Atmospheric Science, Dalhousie University, Halifax, Canada \\ ${ }^{6}$ US Environmental Protection Agency, Research Triangle Park, NC, USA \\ * now at: Earth Observatory of Singapore, Nanyang Technological University, Singapore
}

Correspondence to: C. L. Heald (heald@mit.edu)

Received: 18 July 2012 - Published in Atmos. Chem. Phys. Discuss.: 6 August 2012

Revised: 18 October 2012 - Accepted: 30 October 2012 - Published: 6 November 2012

\begin{abstract}
We use in situ observations from the Interagency Monitoring of PROtected Visual Environments (IMPROVE) network, the Midwest Ammonia Monitoring Project, 11 surface site campaigns as well as Infrared Atmospheric Sounding Interferometer (IASI) satellite measurements with the GEOS-Chem model to investigate inorganic aerosol loading and atmospheric ammonia concentrations over the United States. IASI observations suggest that current ammonia emissions are underestimated in California and in the springtime in the Midwest. In California this underestimate likely drives the underestimate in nitrate formation in the GEOSChem model. However in the remaining continental United States we find that the nitrate simulation is biased high (normalized mean bias $>=1.0$ ) year-round, except in Spring (due to the underestimate in ammonia in this season). None of the uncertainties in precursor emissions, the uptake efficiency of $\mathrm{N}_{2} \mathrm{O}_{5}$ on aerosols, $\mathrm{OH}$ concentrations, the reaction rate for the formation of nitric acid, or the dry deposition velocity of nitric acid are able to explain this bias. We find that reducing nitric acid concentrations to $75 \%$ of their simulated values corrects the bias in nitrate (as well as ammonium) in the US. However the mechanism for this potential reduction is unclear and may be a combination of errors in chemistry, deposition and sub-grid near-surface gradients. This "updated"
\end{abstract}

simulation reproduces PM and ammonia loading and captures the strong seasonal and spatial gradients in gas-particle partitioning across the United States. We estimate that nitrogen makes up 15-35\% of inorganic fine PM mass over the US, and that this fraction is likely to increase in the coming decade, both with decreases in sulfur emissions and increases in ammonia emissions.

\section{Introduction}

Ammonia $\left(\mathrm{NH}_{3}\right)$ is the most abundant form of gas-phase reduced nitrogen in the atmosphere and contributes to both the formation of particulate matter (PM) and the deposition of reactive nitrogen to the environment. Particulate matter in the atmosphere degrades air quality and visibility and can modify the radiative balance of the Earth both directly and indirectly through the formation of cloud droplets. Human morbidity has been shown to increase linearly with PM concentrations (Dockery et al., 1993; Pope et al., 2009), even at low $\left(<10 \mu \mathrm{g} \mathrm{m}^{-3}\right)$ concentrations (Crouse et al., 2012) suggesting that while air quality standards are set to protect human health, there are no "safe" levels of PM. Typically over half of the fine PM in the United States is made up of inorganic 
aerosol (defined here as the sum of: sulfate, nitrate and ammonium) (NARSTO, 2004). These aerosols are formed in the atmosphere from gas-phase precursors (sulfur dioxide, nitrogen oxides and ammonia), which are largely emitted from anthropogenic activity, including agriculture. The formation of these aerosols is thermodynamically linked, with ammonium nitrate formation generally taking place only when sulfate has been fully neutralized. Ammonia sources have increased through the 20th century with industrial fertilizer production (Erisman et al., 2008), provoking concerns regarding excess nitrogen deposition to sensitive ecosystems (Beem et al., 2010). Recent trends in wet deposition and air quality indicate that the relative role of reduced vs oxidized nitrogen is changing (Pinder et al., 2011). Thus ammonia and particulate nitrogen play important roles in both air quality and ecosystem health.

Model studies suggest that the reduction of $\mathrm{SO}_{2}$ emissions in the US may shift aerosol composition towards nitrate formation (e.g. Pye et al., 2009) and that ammonia emissions control could play an increasing role in achieving compliance with air quality standards (Pinder et al., 2008; Pinder et al., 2007). While such predictions are predicated on accurate model descriptions of both ammonia and the complete inorganic gas-particle system, there have been few observational constraints available to verify the fidelity of these models. This is largely the result of the challenges of measuring ammonia, a sticky, semi-volatile compound with ambient concentrations that vary over several orders of magnitude (von Bobrutzki et al., 2010). Model simulations have been widely validated against surface network observations of inorganic aerosol concentrations and wet deposition (e.g. Park et al., 2004; Adams et al., 1999; Bessagnet et al., 2004). Observations of gas-phase precursors alongside aerosol concentrations are more rare. Efforts have been made to optimize inorganic aerosol precursor emissions based on observed particle concentrations (Henze et al., 2009), however errors in PM formation and loss may cloud the links between precursor emissions and ambient particle concentrations. Recently, infrared satellite instruments have demonstrated the capability to measure ammonia from space (Beer et al., 2008; Clarisse et al., 2009). The spatial and continuous global coverage of such observations provides critical complementarity to specific field campaign observations. However, the sensitivity of these infrared sounders can be limited, particularly as atmospheric ammonia is largely present in the boundary layer, where thermal contrast can be low. Our goal here is to apply a series of unique satellite and surface inorganic measurements to investigate both atmospheric ammonia and particle phase nitrogen in the United States.

Thermodynamic models have been developed to describe the partitioning of semi-volatile species. Several studies have confirmed that the assumption of equilibrium partitioning is valid for ambient aerosol (e.g. Ellis et al., 2011; Nowak et al., 2010; Nowak et al., 2006). Thus 3-D model simulation errors are not likely to result from errors in the description of thermodynamic partitioning but rather from (1) errors in precursor emission estimates (2) errors in formation of sulfate or nitric acid (3) biases in temperature and humidity leading to biased gas-particle partitioning or (4) errors in gas and particle deposition. Here we investigate the skill of the GEOS-Chem global model in reproducing regional ammonia loadings and inorganic concentrations and partitioning. We note that the study of Walker et al, (2012), completed at the same time as this work, addresses some of the same issues, with a focus on California, and reports similar results to those presented here. Our objective is to identify obvious biases in the key processes outlined above and to suggest what kind of field measurements could be particularly valuable. Routine measurement of ammonia will be added in the coming years to select sites in the IMPROVE network in the United States, providing additional constraints on inorganic gas-particle partitioning. These future observations and those discussed herein can contribute to an improved understanding of the complete inorganic system. This will be critical to the accurate interpretation of new satellite observations of ammonia and resulting estimates of the role of nitrogen in PM formation, climate, and ecosystem health.

\section{Measurement description}

\subsection{IMPROVE network aerosol measurements and the Midwest Ammonia Monitoring Project}

The Interagency Monitoring of PROtected Visual Environments (IMPROVE) network of stations was established in 1987 to monitor visibility in national parks and other protected environments in the United States (Malm et al., 1994). Surface concentrations of fine particle $\left(\mathrm{PM}_{2.5}\right)$ sulfate, nitrate, organic carbon and elemental carbon are measured as 24-h averages every third day. The ammonium ion is not routinely measured in the IMPROVE network. Nitrate (and sulfate) are collected on a Nylasorb substrate after passing through a carbonate denuder tube, minimizing both nitrate volatilization and gas-phase contamination (Malm et al., 2004). We show here comparisons at 238 sites operating in 2004 in the continental United States.

We also examine measurements from the Midwest Ammonia Monitoring Project $\left(\mathrm{MWNH}_{3}\right)$, a field intensive at 10 sites (9 co-located at IMPROVE sites) from November 2003 through October 2005 (Blanchard and Tanenbaum, 2005; Sweet et al., 2005). We show only measurements from 2004. Measurements of fine particle sulfate, nitrate, ammonium as well as gas-phase ammonia, nitric acid and sulfuric acid were collected every 6th day by the Illinois State Water Survey. The measurement system consisted of two denuders, one to collect $\mathrm{HNO}_{3}$ and $\mathrm{SO}_{2}$ and the second to collect $\mathrm{NH}_{3}$, followed by a Teflon and Nylon filter to collect the particles. Measured sulfate and nitrate agreed well with co-located IMPROVE measurements (Blanchard and Tanenbaum, 2005). 


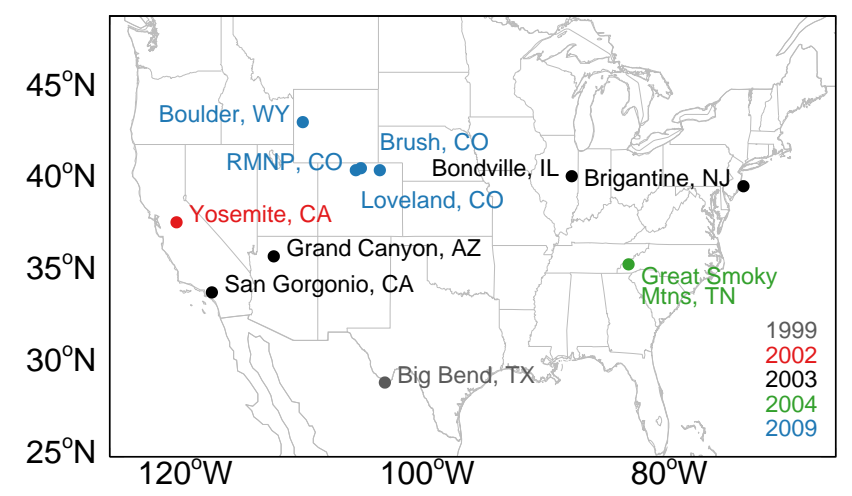

Fig. 1. Surface measurement site locations, colored by year of measurement.

\subsection{In situ measurements}

Several field experiments were designed and conducted to investigate the chemical composition of $\mathrm{PM}_{2.5}$ aerosol and the concentrations of trace gases $\left(\mathrm{HNO}_{3}, \mathrm{NH}_{3}\right.$ and $\left.\mathrm{SO}_{2}\right)$ at monitoring locations for the IMPROVE program from the late 1990's through 2010 (Fig. 1). Daily 24-h measurements were made in a variety of seasons during 1999, 2002, 2003 and 2004. Study sites included Big Bend National Park (July-October 1999), Yosemite National Park (July-September 2002), Bondville, Illinois (February 2003), San Gorgonio Wilderness Area, California (April and July 2003), Grand Canyon National Park, Arizona (May 2003), Brigantine National Wildlife Refuge, New Jersey (November 2003), and Great Smoky Mountains National Park, Tennessee (July/August 2004). Aerosol composition measured at these sites has previously been reported (Yu et al., 2005b, 2006; Lee et al., 2004, 2008a). In addition, a series of yearlong intensive measurements were made in Rocky Mountain National Park (November 2008-October 2009, daily), Boulder, WY (December 2006-December 2010, 3 and 4day average), and Brush and Loveland, CO (December 2008November 2009, weekly average).

A URG (University Research Glassware) cyclone/annular denuder/filter pack system was used for $\mathrm{PM}_{2.5}$ and trace gas $\left(\mathrm{HNO}_{3}, \mathrm{NH}_{3}\right.$ and $\left.\mathrm{SO}_{2}\right)$ sampling. Ambient air is drawn into the URG sampler through a cyclone ( $\left.\mathrm{D}_{50}=2.5 \mu \mathrm{m}, 10 \mathrm{LPM}\right)$, and through two denuders in series for collection of the gaseous species of interest. $\mathrm{Na}_{2} \mathrm{CO}_{3}$ (or $\mathrm{NaCl}$ for Big Bend NP and Boulder, WY) coated the first denuder for collection of gaseous $\mathrm{HNO}_{3}$ and $\mathrm{SO}_{2}$ and the second denuder was coated with phosphorus acid (or citric acid for Big Bend NP) to collect gaseous $\mathrm{NH}_{3}$. $\mathrm{SO}_{2}$ concentrations are not measured at Big Bend NP or in Boulder, WY. The air stream continued through either a nylon filter (Nylasorb, $1.0 \mu \mathrm{m}$ pore size, Pall Corporation) and a backup phosphorus acid-coated denuder or a 3-stage filter pack with a Teflon filter (Teflo, $2.0 \mu \mathrm{m}$ pore size, Pall Corporation), a nylon filter (Nylasorb, $1.0 \mu \mathrm{m}$ pore size, Pall Corporation) and a backup citric acid-coated cel- lulose filter (or quartz filter). Sampling at the ammonia-rich Brush, $\mathrm{CO}$ site was performed with a lower flow rate (3 LPM) and with an extra ammonia denuder before the filter to ensure that ammonia collection capacity was not exceeded. Analysis of $\mathrm{PM}_{2.5}$ filter and denuder extracts focused on the main $\mathrm{PM}_{2.5}$ ionic species $\left(\mathrm{SO}_{4}^{2-}, \mathrm{NO}_{3}^{-}, \mathrm{NH}_{4}^{+}\right)$, and trace gases $\left(\mathrm{HNO}_{3}, \mathrm{NH}_{3}\right.$ and $\left.\mathrm{SO}_{2}\right)$. Sampling and analysis details are described in detail elsewhere (Yu et al., 2005b; Lee et al., 2004; Lee et al., 2008b). Species detection limits were typically $20-70 \mathrm{ng} \mathrm{m}^{-3}$ while measurement precisions were typically in the range of 3-9\% (RSD) for individual samples, but are correspondingly smaller for the monthly or seasonal means shown here. Accuracy checks on key components of the measurement (sample volume, extract volume, and ion concentration) typically reveal biases of a few percent, with a range from approximately $1-10 \%$. $\mathrm{PM}_{2.5}$ ion concentrations measured with the URG compare well $\left(R^{2}>0.9\right.$ and mean biases less than $10 \%$ across the US) with online measurements, as discussed by Lee et al. (2008b).

\subsection{Infrared Atmospheric Sounding Interferometer (IASI)}

The Infrared Atmospheric Sounding Interferometer (IASI) was launched aboard the MetOp-A platform in October 2006. This nadir sounder provides global measurements of a suite of atmospheric trace gases, including ammonia (Clerbaux, 2009). The instrument footprint $(12 \mathrm{~km} \times 12 \mathrm{~km})$ is combined with extensive cross-track scanning $(2200 \mathrm{~km})$ to provide detailed global daily coverage. Measurements from sun-synchronous polar orbit are made twice daily at 9:30 and 21:30 local time.

Ammonia retrievals are based on an absorption feature $\sim 950 \mathrm{~cm}^{-1}$. Initial global retrievals reported by Clarisse et al. (2009) were based on a brightness temperature scaling approach, but here retrievals apply formal optimal estimation methods (Rodgers, 2000) to retrieve the profile of ammonia $(\hat{\mathbf{x}})$ :

$\hat{\mathbf{x}}=\mathbf{x}_{\mathrm{a}}+\mathbf{A}\left(\mathbf{x}-\mathbf{x}_{\mathrm{a}}\right)+\varepsilon$

where $\mathbf{x}$ is the true profile, $\mathbf{x}_{\mathrm{a}}$ is the a priori constraint, which is a constant global moderately polluted mean profile from the TM5 model, and $\varepsilon$ is the spectral measurement error. The averaging kernels (A) describe the vertical sensitivity of the instrument and depend on the thermal contrast and vertical distribution of ammonia. IASI $\mathrm{NH}_{3}$ measurements are generally most sensitive at $1-2 \mathrm{~km}$ altitude, where concentrations are highest and thermal contrast is sufficient for detection. Thermal contrast is also highest during daytime, and therefore only daytime retrievals are used here. Retrieved ammonia is shown here as an integrated column concentration given the low vertical sensitivity.

The retrievals are performed in near real time using the fast radiative transfer model FORLI (Hurtmans et al., 2012). Note that with the constraints applied to allow for global retrievals, 
the averaging kernels and degrees of freedom (DOF) are unrealistically small for this research product (typically $<0.3$ over the continental United States), especially in comparison to the initial work of Clarisse et al. (2010) over the San Joaquin Valley. This does not impact the quality of the retrievals; however, low DOFs imply larger reliance on the a priori when attempting to compare the IASI retrievals with other measurements or models. This is discussed further in Sect. 4.2.

\section{Model description}

We compare here measurements of the inorganic gasparticle system with the GEOS-Chem global model of atmospheric chemistry (www.geos-chem.org). We employ v9-0101 of the model driven by GEOS-5 assimilated meteorology from the NASA Global Modeling and Assimilation Office (GMAO). We conduct a series of coupled oxidant-aerosol nested grid simulations $\left(0.5^{\circ} \times 0.67^{\circ}\right.$ horizontal resolution) (Chen et al., 2009) over North America for three years (2004, 2009 and 2010) and show results over the continental United States. Boundary conditions are from global simulations performed at $2^{\circ} \times 2.5^{\circ}$ horizontal resolution for the same years.

The GEOS-Chem oxidant-aerosol simulation includes $\mathrm{H}_{2} \mathrm{SO}_{4}-\mathrm{HNO}_{3}-\mathrm{NH}_{3}$ aerosol thermodynamics coupled to an ozone- $\mathrm{NO}_{\mathrm{x}}$-hydrocarbon-aerosol chemical mechanism (Park et al., 2004). Partitioning of total ammonia and nitric acid between the gas and particle phases is calculated using the ISORROPIA II thermodynamic equilibrium model (Fountoukis and Nenes, 2007) as implemented in GEOS-Chem by Pye et al. (2009). The gas-particle equilibrium considers sodium and chloride from accumulation mode sea salt as well as sulfate, nitrate and ammonium. Formation of inorganic aerosol on coarse mode dust and sea salt is excluded, thus estimated aerosol concentrations represent $\mathrm{PM}_{2.5}$ concentrations. In this implementation of ISORROPIA the inorganic aerosol are assumed to be metastable on the upper branch of the hygroscopicity hysteresis curve. The metastable assumption likely holds near the surface where relative humidities exceed the deliquescence relative humidity on a daily basis, but may not be appropriate in the free troposphere (Wang et al., 2008).

Anthropogenic emissions of aerosol precursors over the US are specified according to the US EPA National Emission Inventory for 2005 (NEI05, with seasonality as in Park et al. (2004)), with biofuel emissions from the US EPA National Emission Inventory for 1999 (NEI99) and yearspecific biomass burning from the GFED2 inventory (van der Werf et al., 2006). Anthropogenic emissions are scaled to the model year following national energy use statistics as described by van Donkelaar et al. (2008). Natural and agricultural ammonia emissions in GEOS-Chem follow the global inventory of Bouwman et al. (1997) with seasonal variation as described by Park et al. (2004). Natural emissions of
DMS, $\mathrm{NO}_{\mathrm{x}}$ from lightning and soils, and sea salt depend on meteorology and are computed online in the model (see description in Pye et al., 2009). Emission totals for ammonia, $\mathrm{NO}_{\mathrm{x}}$ and $\mathrm{SO}_{\mathrm{x}}$ over the United States for 2004 are given in Table 1.

Wet deposition of soluble aerosols and gases follows the scheme of Liu et al. (2001) including contributions from scavenging in convective updrafts, rainout, and washout. Dry deposition follows a standard resistance-in-series model (Wesely, 1989) and is discussed further in Sect. 4.3.

The GEOS-5 meteorology fields used here suffer from an artifically low mixed layer depth at nightime which can produce large biases in simulated nighttime surface concentrations (and thus 24-h or monthly means). We implement a correction to the standard v9.01.01 version of GEOS-Chem by restricting the mixed layer depth from dropping below a minimum mechanical mixing depth, defined as a function of local friction velocity (Lin and McElroy, 2010; Koracin and Berkowicz, 1988). This restriction increases mean nighttime mixed layer depths by a factor or two and bring them in line with values measured at the ARM-Southern Great Plains site (Liu and Liang, 2010). This also elimiated the erroneously large increases in nitrate concentrations at night, decreasing annual mean nitrate concentrations across the US by $20 \%$ on average.

Previous studies using GEOS-Chem and the MARS-A thermodynamic scheme have shown large biases (up to a factor of two) in simulated nitrate over the United States (Park et al., 2004; Henze et al., 2009). Recent evaluation of the inorganic aerosol simulation using ISORROPIA also shows large biases in nitrate, which is overestimated by GEOS-Chem in the Eastern US and underestimated in the Western US (Pye et al., 2009). Zhang et al. (2012), using a similar model configuration to our work (but using the MARS-A scheme), show that both nitric acid and ammonium nitrate concentrations are overestimated in the model when sulfate is unbiased, particularly in wintertime. They suggest that this is the result of excessive $\mathrm{HNO}_{3}$ formation via $\mathrm{N}_{2} \mathrm{O}_{5}$ hydrolysis. In addition, they show that ammonia measurements in the upper Midwest support an increase in springtime emissions compared to the standard seasonality applied in GEOS-Chem based on Park et al. (2004).

We build on this work by bringing new measurements of both ammonia (satellite) and gas-particle partitioning (in situ) to bear on the inorganic system. We evaluate daily mean concentrations simulated for 2004 with the URG observations from 1999, 2002, 2003 and 2004 described in Sect. 2. Thus interannual variability in meteorology may degrade the comparison, particularly the ability to reproduce daily variability. The same 2004 simulation is compared to monthly mean measurements across the IMPROVE network and the Midwest Ammonia Monitoring Project. Monthly mean measurements from 2009 in Wyoming and Colorado are compared to the 2009 simulation. For comparison with IASI measurements we match simulated ammonia profiles with the 


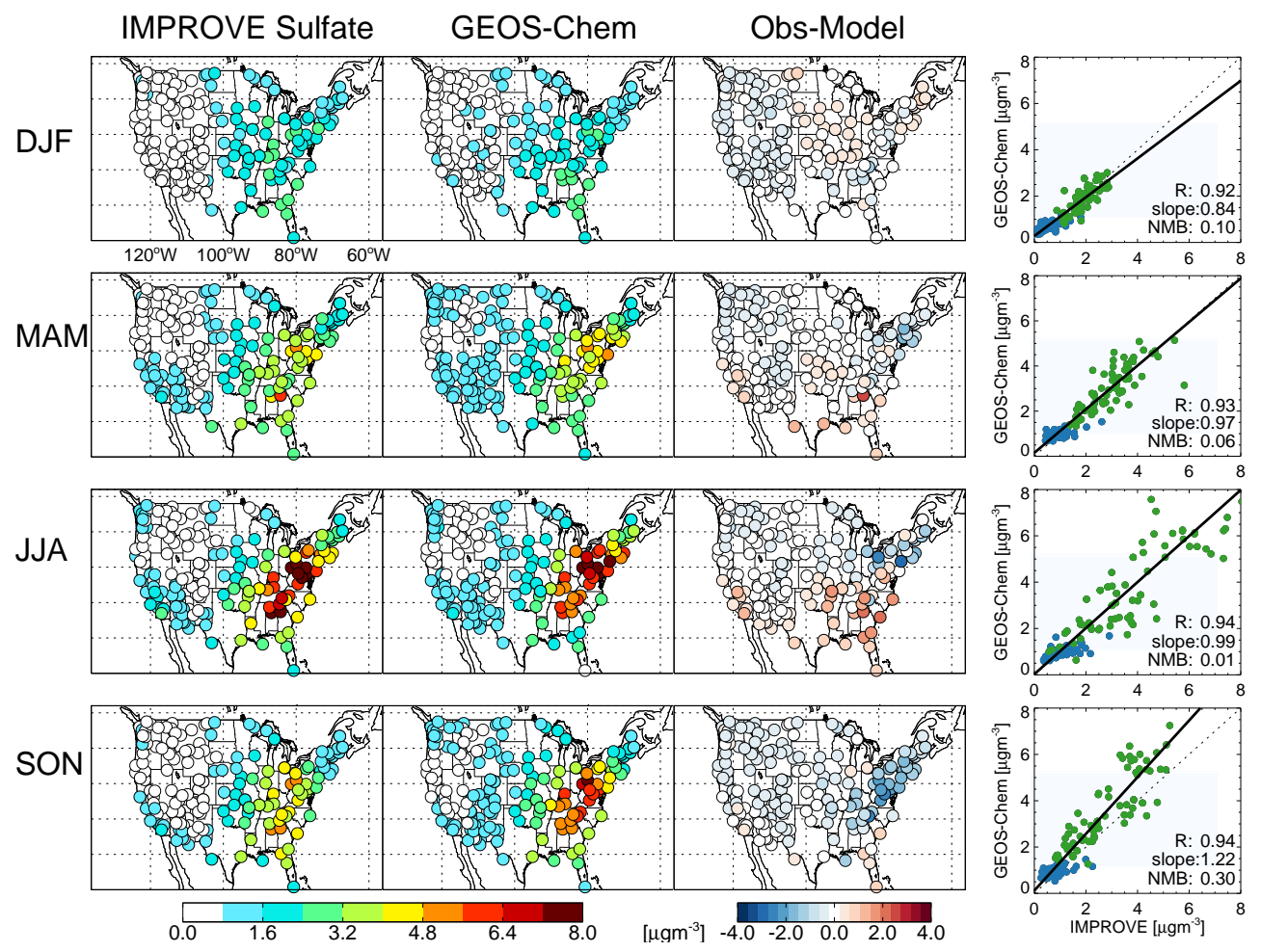

Fig. 2. Sulfate mean seasonal surface concentrations measured, simulated with GEOS-Chem (baseline simulation), and the difference at IMPROVE sites in 2004. Scatterplot of seasonal means also shown with reduced-major-axis regression fit (solid black line). Correlation coefficient $(R)$, slope and normalized mean bias (NMB) shown in inset. Sites located west of $100^{\circ} \mathrm{W}$ shown in blue, sites east of this longitude shown in green (longitude labels given in top panel for reference).

location and time of each retrieval and then apply the IASI averaging kernel and a priori ammonia profile as in Eq. (1), and integrate over the vertical column. The paired comparisons are then re-gridded to the GEOS-Chem horizontal resolution.

\section{Results}

\subsection{Initial fine PM evaluation}

The over 200 IMPROVE stations reporting surface $\mathrm{PM}_{2.5}$ composition in 2004 provide dense coverage of the United States and a good basis for model evaluation. Figure 2 shows that the model reproduces the spatial and seasonal distribution of observed sulfate in 2004, with a small positive bias in the Northeast in the summer/fall (responsible for the normalized mean bias of 0.30 in the Fall; $\mathrm{NMB}=\Sigma_{i} M_{i}-\mathrm{O}_{i} / \Sigma_{i} \mathrm{O}_{i}$, where $\mathrm{O}_{i}=$ observed values and $\mathrm{M}_{i}=$ model values) and a small underestimate in the Southeast in summertime. However regression slopes between observed and simulated means are close to unity, with the exception of the Northeast in the fall, and thus these errors do not substantially degrade the model simulation of PM.
Figure 3 shows the same comparison for nitrate. The model captures the large scale patterns and seasonality, with two obvious, significant biases. Nitrate concentrations are underestimated in California, possibly due to an underestimate of ammonia or nitrogen oxide emissions in the region. The model underestimate of nitrate in the southwest may also be associated with the failure to represent coarse mode nitrate on dust, the tail of which Lee et al. (2008a) show can be included in $\mathrm{PM}_{2.5}$ measurements. Nitrate concentrations are overestimated in the rest of the United States year-round. This is consistent with the overestimate reported in other studies using both GEOS-Chem and other models (Pye et al., 2009; Henze et al., 2009; Zhang et al., 2012; Yu et al., 2005a; Walker et al., 2012). Note that regression lines and NMB statistics are shown separately for the Eastern and Western US to demonstrate these differences. In the Eastern United States normalized mean biases are close to or greater than 1.0 in all seasons, except spring. Similar biases are seen with respect to CASTNet network observations of both nitrate and ammonium (not shown here, but reported by Zhang et al. (2012)). However CASTNet measurements do not provide a good quantitative test of the fine PM simulation given that measurements may include contamination from coarse mode nitrate (no size-selective sampling) which can be significant (Lee et al., 2008a), and CASTNet ammonium nitrate 

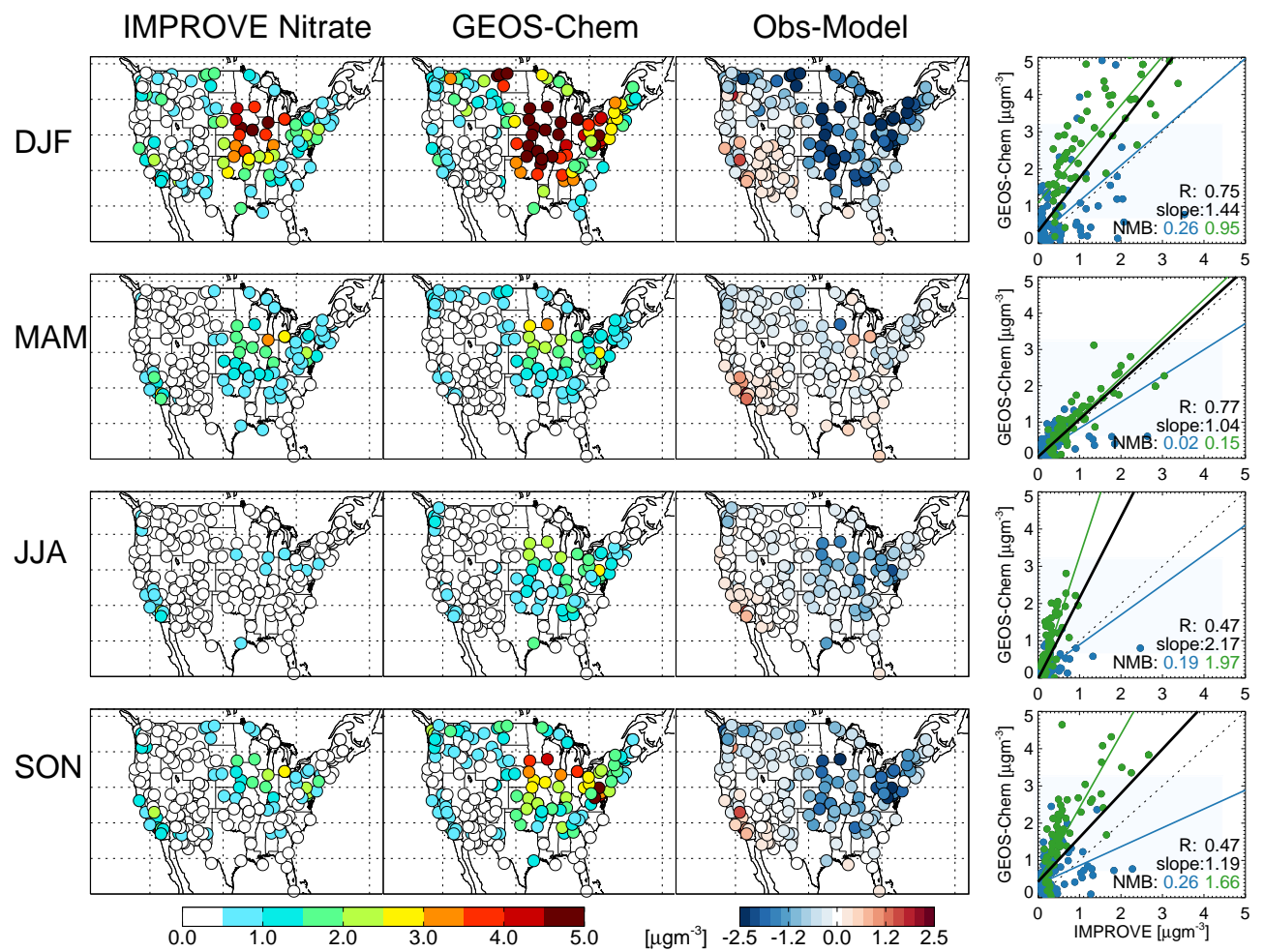

Fig. 3. Nitrate mean seasonal surface concentrations measured, simulated with GEOS-Chem (baseline simulation), and the difference at IMPROVE sites in 2004. Scatterplot of seasonal means also shown with reduced-major-axis regression fit (solid black line). Sites located west of $100^{\circ} \mathrm{W}$ shown in blue, sites east of this longitude shown in green, with reduced-major-axis regression fits for each shown separately as solid lines. Correlation coefficient $(R)$, slope and normalized mean bias (NMB) for east and west region shown in inset.

measurements are more susceptible to re-volatilization errors from the Teflon filters used (Ames and Malm, 2001).

Potential causes for the nitrate overestimate seen in Fig. 3 include (1) overestimated precursor emissions of either ammonia or nitrogen oxides (2) excess nitric acid formation (3) an underestimate in nitrate (or nitric acid) deposition (4) a cold or wet bias in the model that favors excess ammonium nitrate formation or (5) the absence of $\mathrm{HNO}_{3}$ reactions with coarse mode PM. We explore the bias in simulated nitrate in the following sections.

\subsection{Investigating ammonia emissions}

Extensive evaluation of the GEOS-Chem in the US against aircraft and satellite observations effectively precludes errors in $\mathrm{NO}_{\mathrm{x}}$ emissions as the source of the observed nitrate bias (Lamsal et al., 2011; Zhang et al., 2012; Martin et al., 2006). However, ammonia emissions are poorly constrained.

Figure 4 compares seasonal gridded mean ammonia concentrations observed by the IASI instrument with the GEOSChem simulation from May 2009 through April 2010. Only gridboxes with at least 4 observations during a season are shown in order to avoid drawing conclusions from limited, variable measurements. We first show the number of retrievals averaged in each gridbox, to demonstrate both the extensive cross-track coverage of IASI, and the seasonal variability in the number of successful retrievals of ammonia. This is most likely due to cloud coverage, particularly in the fall and winter. We also see in Fig. 4 the high degree of reliance on the a priori in the retrieval. This is particularly evident when comparing the native GEOS-Chem simulation with the "retrieved" simulation where the IASI ammonia averaging kernel and a priori are applied as in Eq. (1). Both the IASI and GEOS-Chem retrieved values rarely drop below the a priori column concentration $\left(\sim 0.3 \times 10^{16}\right.$ molecules $\left.\mathrm{cm}^{-2}\right)$ and seasonality is reduced, consistent with the reported characteristics of the ammonia retrievals for the Tropospheric Emission Spectrometer (TES) (Shephard et al., 2011). Furthermore, all the features of the GEOS-Chem ammonia distribution are considerably damped by application of the averaging kernel.

IASI ammonia concentrations peak in the springtime in the Midwest, in contrast with simulated concentrations which peak in the summertime. However, comparison of the native and retrieved GEOS-Chem fields suggest that IASI sensitivity in the Midwest may be lower in the summer than the springtime, which may contribute to this apparent difference. The distribution of simulated ammonia agrees reasonably well in the region in summertime, but the comparison suggests that springtime ammonia emissions are far too low 

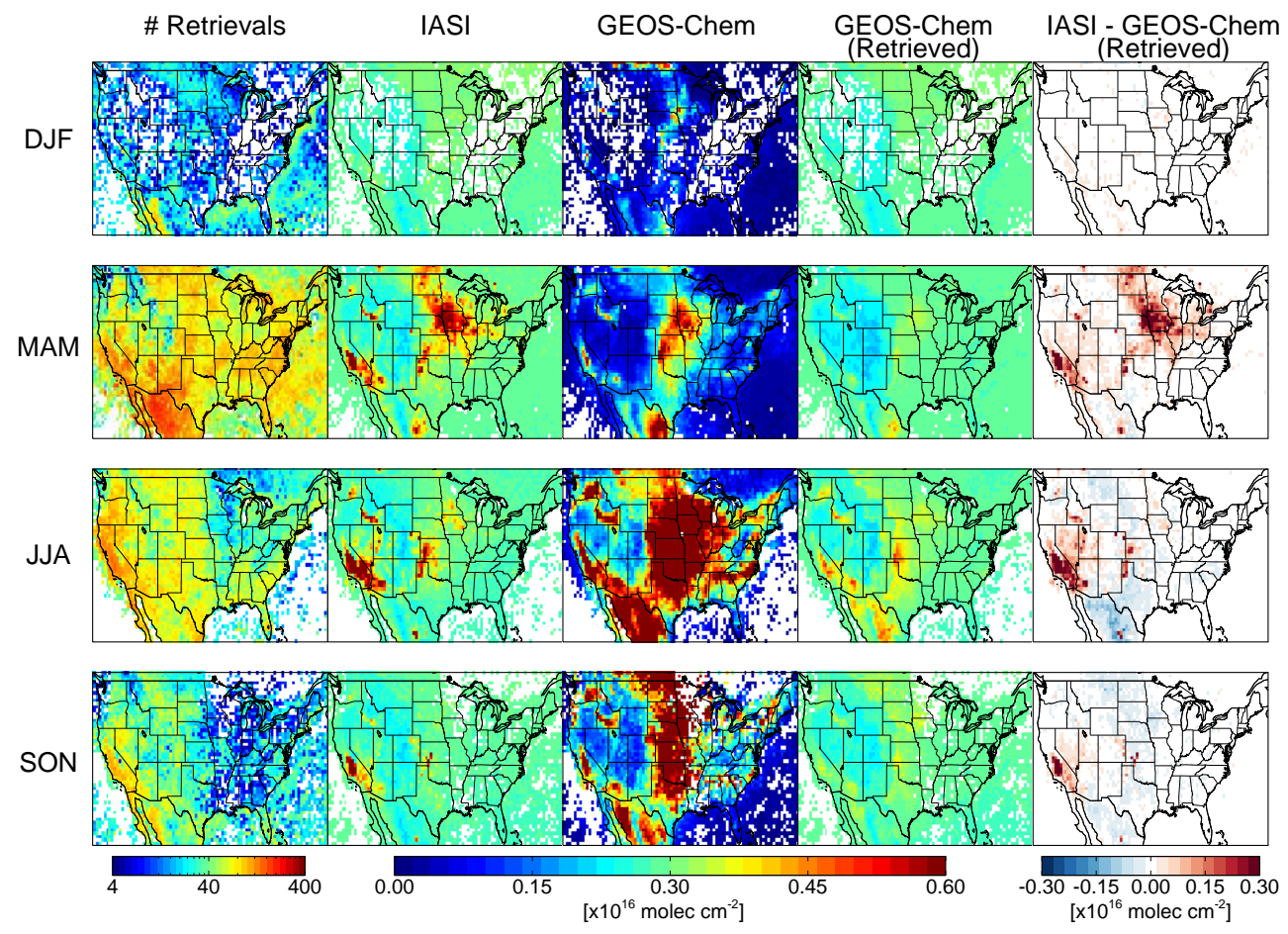

Fig. 4. Comparison of atmospheric ammonia column concentrations observed by IASI and simulated with the baseline GEOS-Chem model over the United States from May 2009 through April 2010. The IASI retrieval averaging kernel and a priori have been applied to the GEOSChem simulation as in Eq. (1) (4th column) for quantitative comparison with the satellite observations. Gridded model and observations only shown in gridboxes with 4 or more retrievals per season. Color scales are saturated at respective values.

Table 1. Continental US emissions for 2004. Ammonia emissions with "new seasonality" shown in brackets (see Sect. 4.2).

\begin{tabular}{ll}
\hline Species & Emission \\
\hline Ammonia $\left(\mathrm{NH}_{3}\right)$ & $2.8(3.3) \mathrm{TgNyr}^{-1}$ \\
Anthropogenic & $2.0(2.5)$ \\
Biofuel & 0.2 \\
Biomass Burning & 0.002 \\
Natural & 0.6 \\
\hline Sulfur Oxides $\left(\mathrm{SO}_{x}\right)$ & $6.8 \mathrm{Tg} \mathrm{S} \mathrm{yr}^{-1}$ \\
Anthropogenic & 6.7 \\
Biofuel & 0.001 \\
Aircraft & 0.01 \\
Biomass Burning & 0.09 \\
Volcanic & 0.02 \\
\hline Nitrogen Oxides $\left(\mathrm{NO}_{x}\right)$ & $6.8 \mathrm{Tg} \mathrm{N} \mathrm{yr}^{-1}$ \\
Anthropogenic & 5.5 \\
Biofuel & 0.01 \\
Aircraft & 0.2 \\
Fertilizer & 0.09 \\
Biomass Burning & 0.03 \\
Lightning & 0.7 \\
Soil & 0.4 \\
\hline
\end{tabular}

in GEOS-Chem. This is consistent with Zhang et al. (2012) who find that comparisons with the $\mathrm{MWNH}_{3}$ observations support a broadening of the $\mathrm{NH}_{3}$ emission peak from summer into spring and fall, with more than a doubling of March and April emissions. Total US ammonia emissions increase by $18 \%$ (see Table 1). Some previous studies also support a springtime peak in ammonia emissions in the United States (Pinder et al., 2006; Gilliland et al., 2006); however, optimized ammonia emissions from Henze et al.(2009) peak in the summertime. These differences in part confirm the challenge of constraining ammonia emissions from wet deposition or aerosol measurements as done in the preceding studies. The increase in springtime ammonia concentrations resulting from applying the Zhang et al. (2012) seasonality in GEOS-Chem is washed out when the IASI averaging kernels are applied and does not close the gap with the IASI observations. In fact, an extremely large and likely unrealistic increase in ammonia concentrations (in excess of a factor of 5) would be required to reconcile the GEOS-Chem simulation with the IASI measurements over the Midwest. As discussed in Sect. 2.3 this is due to the artificially low IASI degrees of freedom for signal such that the averaging kernels do not accurately represent the balance between a priori and detected information in the retrieval. Thus, for this study, the IASI retrievals are only used qualitatively. In light of this, we conclude that IASI measurements support the 


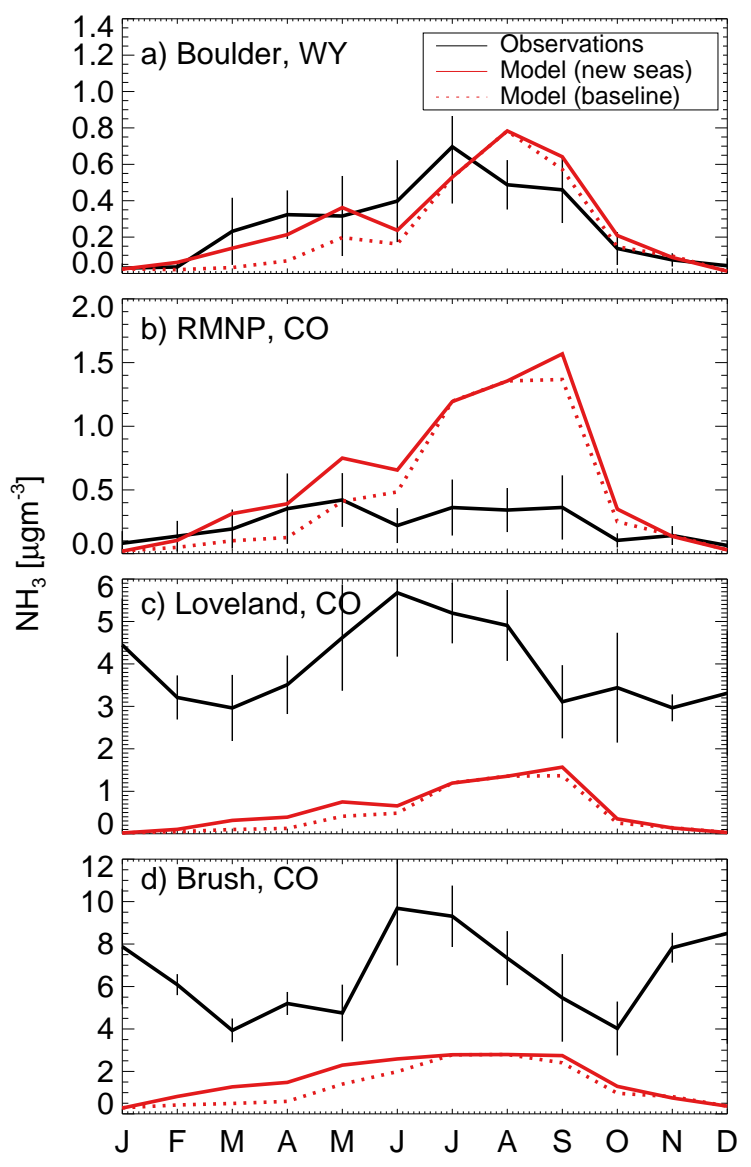

Fig. 5. Timeseries of year-long monthly mean ammonia concentrations measured (black) and simulated (red) in 2009 at 4 sites (from west to east): (a) Boulder, WY, (b) Rocky Mountain National Park, $\mathrm{CO}$, (c) Loveland, $\mathrm{CO}$ and (d) Brush, CO. Both the baseline simulation (dotted) and simulation with updated ammonia emissions seasonality (solid) are shown. Standard deviations of the individual observations averaged for each month are shown as error bars.

springtime enhancement of ammonia emissions suggested by Zhang et al. (2012) and include this increase in the comparisons that follow (referred to as "New $\mathrm{NH}_{3}$ Seasonality"). Wells et al. (2012) find a similar springtime underestimate of methanol in the GEOS-Chem simulation compared to the IASI methanol retrievals, which they attribute to an underestimate of biogenic emissions from new leaves in mid-latitude ecosystems. Ammonia emissions from vegetation are negligible (Guenther et al., 2012), thus enhanced springtime emissions are far more likely associated with agricultural practices, for example earlier fertilizer application in the Midwest, or seasonal changes in cattle feed availability and associated emissions (Hristov et al., 2011).

Figure 4 also indicates that ammonia emissions in California and particularly in the San Joaquin Valley (SJV) are underestimated in GEOS-Chem. This mainly rural and agricultural region features some of the largest ammonia emissions in the country (Goebes et al., 2003; Makar et al., 2009), and regularly reports some of the highest PM loading in the United States (Chow et al., 1996; Watson et al., 2000), leading to frequent violations of the National Ambient Air Quality Standards. Clarisse et al. (2010) previously estimated that mean summertime surface ammonia concentrations in the SJV regionally exceed $15 \mathrm{ppb}$. Figure 4 shows that California is well-observed by IASI, with the exception of the wintertime, and while the spatial and seasonal patterns of enhanced ammonia are captured by GEOS-Chem, GEOSChem concentrations significantly underestimate IASI from spring through fall. Retrieval characteristics preclude a quantitative estimate of the associated emissions gap (see previous discussion); however, an underestimate in ammonia in the region is consistent with the ammonium nitrate formation underestimate implied by the nitrate underestimate in the region (Fig. 3), as also suggested by Walker et al. (2012). Nowak et al. (2012) report an underestimate of dairy emissions in the South Coast Air Basin in the NEI-05 emission inventory which could contribute to the underestimate in California.

Figure 5 presents a further evaluation of simulated ammonia, which illustrates some of the challenges associated with local comparisons and strong regional gradients. We compare simulated and measured ammonia at four field sites located in some proximity (within $700 \mathrm{~km}$, Fig. 1). The model (with "New $\mathrm{NH}_{3}$ Seasonality" emissions as discussed above) reproduces ammonia well at the rural site in Wyoming which is removed from local sources. The Colorado sites represent a strong west to east gradient from the very clean Rocky Mountain National Park to Brush, $\mathrm{CO}$ which is east and often down-wind of one of the largest inventories of cattle in the United States (Weld County). Observed monthly mean ammonia concentrations increase more than 20 -fold across this gradient, while model concentrations at most double. While the underestimation of ammonia emissions associated with these agricultural operations has a limited impact on ammonium nitrate formation in the model (limited by the nitric acid supply), it implies potentially large underestimates of simulated regional nitrogen deposition.

The qualitative information provided by the IASI instrument suggests that the ammonia emissions biases may be responsible for two aspects of the GEOS-Chem nitrate simulation shown in Fig. 3: (1) The underestimate of nitrate in California is associated, at least in part, with an underestimate in ammonia emissions in the region. (2) A springtime underestimate of ammonia emissions in the Midwest masks some of the bias in nitrate present year-round in the simulation. Increasing the ammonia emissions in springtime as suggested by Zhang et al. (2012) increases the nitrate bias seen in Fig. 3 (slope increases from 1.04 to 1.77 - see increase in annual mean nitrate concentrations in Fig. 6). Thus, while further validation of ammonia emission inventories is clearly called for, there is no evidence to suggest that the excess nitrate levels in GEOS-Chem are associated with biases in emissions. 


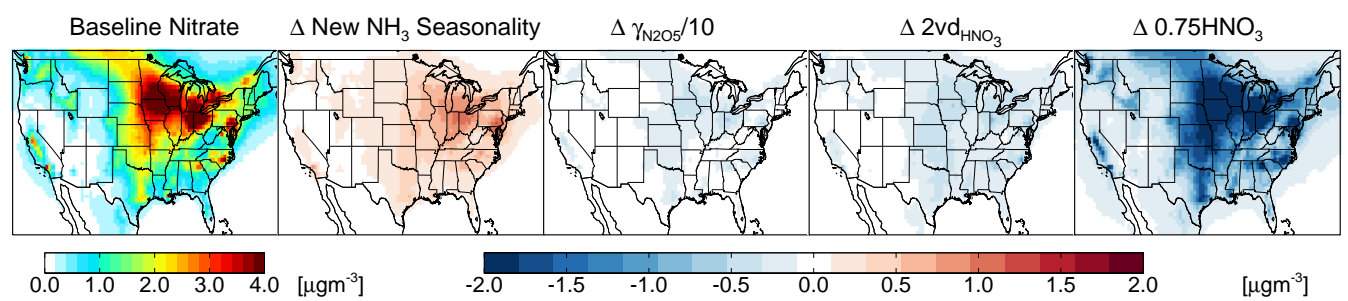

Fig. 6. Annual mean simulated surface nitrate (left) and the difference from this baseline (labeled as $\Delta$ ) for four sensitivity simulations. The four sensitivity simulations are as follows from left to right: (1) The increase in springtime ammonia emissions, (2) the decrease in the uptake coefficient of $\mathrm{N}_{2} \mathrm{O}_{5}$ by a factor of 10, (3) a doubling of the dry deposition velocity for nitric acid and (4) a reduction of nitric acid concentrations to $75 \%$ of baseline values.

\subsection{Further exploration of the nitrate bias}

Alternate explanations for the nitrate bias in the GEOS-Chem model include errors in nitric acid formation or deposition. Surface nitric acid concentrations are challenging to evaluate as a result of the strong vertical gradient associated with surface uptake. Zhang et al. (2012) make an attempt to account for this by adjusting the lowest model gridbox center $(70 \mathrm{~m})$ simulated concentrations to the $10 \mathrm{~m}$ CASTNet measurement altitude using an aerodynamic resistance correction. They report an $18 \%$ annual average high bias in the model following this correction, which they attribute to an overestimation of nitric acid formation via $\mathrm{N}_{2} \mathrm{O}_{5}$ hydrolysis on ammonium nitrate aerosols. However this is unlikely given that McIntyre and Evans (2010) show that the sensitivity of the $\mathrm{NO}_{\mathrm{x}}$ budget to a decrease in the uptake coefficient of $\mathrm{N}_{2} \mathrm{O}_{5}$ is less than $10 \%$ given the current values of the uptake coefficient assumed in GEOS-Chem. This is confirmed in Fig. 6 which shows that nitrate concentrations decrease by less than $10 \%$ when the uptake coefficient of $\mathrm{N}_{2} \mathrm{O}_{5}$ is reduced by an order of magnitude in the model.

Nitric acid formation could also be promoted by an excessively oxidizing environment. However, nitrate concentrations are found to be relatively insensitive to modest changes in $\mathrm{OH}$. A reduction in simulated $\mathrm{OH}$ levels by $25 \%$ does not impact simulated nitrate levels (within $5 \%$ of baseline concentrations), as a reduction in nitric acid formation is somewhat compensated by an increase in lifetime. Similarly, $\sim 15 \%$ overestimation of the reaction rate of $\mathrm{NO}_{2}$ oxidation by $\mathrm{OH}$ suggested by recent studies (Mollner et al., 2010; Henderson et al., 2012), does not significantly impact nitrate concentrations at the surface over the United States (within $5 \%$ of baseline GEOS-Chem simulated concentrations).

An additional sink of nitric acid, not considered in the GEOS-Chem simulation here, is the uptake of nitric acid on coarse mode dust or sea salt (e.g. Goodman et al., 2000; Abbatt and Waschewsky, 1998). Neglecting this effect could lead to a high bias in surface nitric acid, particularly in the southwest near dust sources, and in coastal regions influenced by coarse mode sea salt. However, Fairlie et al. (2010) show that including the uptake of nitric acid on dust in the
GEOS-Chem simulation does not eliminate the nitric acid bias in dusty outflow from Asia. Thus, while this effect may contribute locally to the model overestimate of nitric acid and fine particulate nitrate, it is unlikely that this can explain the fine nitrate surface bias through most of the eastern US.

Ammonium nitrate formation is favored in cold and humid conditions. GEOS-Chem uses assimilated meteorology and thus temperature and relative humidity are unlikely to be subject to large systematic biases. Meteorological parameters are not reported for the IMPROVE sites shown here, but were measured during the field intensives described in Sect. 2.2. A general comparison of 2004 simulated values with the temperature and relative humidity detected at these sites in various years does not reveal any consistent biases. It is therefore highly unlikely that a strong, consistent, yearround, cold and/or wet bias exists in the model which could be the cause of excess ammonium nitrate formation. Such a bias would also imply a corresponding underestimate in nitric acid, which is inconsistent with our simulations and the results of Zhang et al. (2012). We also verify that surface concentrations of ammonium nitrate are insensitive to the metastable assumption employed in our implementation of ISORROPIA II (see Sect. 3).

Errors in deposition of either particle or gas-phase nitrate could contribute to a biased simulation of nitrate. Zhang et al. (2012) show that annual mean wet deposition of nitrate in GEOS-Chem is biased slightly high but within $10 \%$ of measurements from the National Atmospheric Deposition Program (NADP) over the continental United States. Dry deposition of aerosols is size-dependent in the model and any bias in this process would manifest itself in simulated sulfate as well as nitrate. As the sulfate simulation is relatively unbiased and dry deposition of particles makes a minor contribution to total nitrogen deposition (Zhang et al., 2012) we rule this out as a dominant factor in the simulated nitrate overestimate. However, the dry deposition velocity of nitric acid over various land types is considerably larger and not well constrained. Derived estimates from CASTNet sites across the United States vary from 0.8 to $3.3 \mathrm{~cm} \mathrm{~s}^{-1}$ (Clarke et al., 1997). Schwede et al. (2011) show that the choice of deposition models can result in deposition velocities that differ 

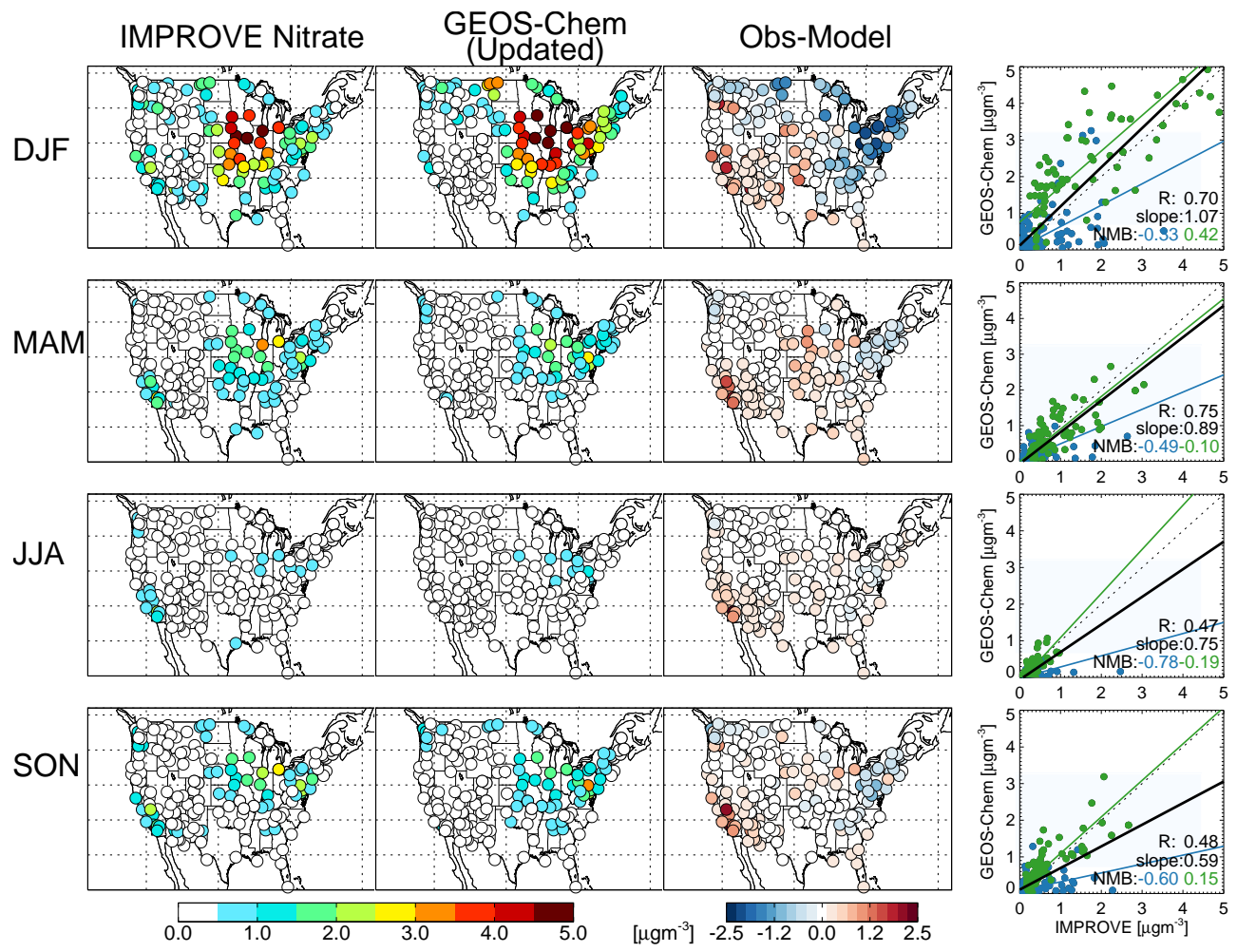

Fig. 7. Nitrate mean 1 seasonal surface concentrations measured, simulated with GEOS-Chem (updated simulation where $\mathrm{HNO}_{3}$ is reduced to $75 \%$ of baseline concentrations), and the difference at IMPROVE sites in 2004. Scatterplot of seasonal means also shown with reducedmajor-axis regression fit (solid black line). Sites located west of $100^{\circ} \mathrm{W}$ shown in blue, sites east of this longitude shown in green, with reduced-major-axis regression fits for each shown separately as solid lines. Correlation coefficient $(R)$, slope and normalized mean bias (NMB) for east and west region shown in inset. Compare to Fig. 3.

by a factor of 2 to 3, and that CASTNet estimates of nitric acid deposition velocities are consistently lower than comparable estimates derived using the CAPMoN network model. Annual mean simulated dry deposition velocities over the continental United States in GEOS-Chem vary from 0.2 to $3.9 \mathrm{~cm} \mathrm{~s}^{-1}$, a similar range to values estimated by CASTNet. Given the poor constraints on this value, we test the sensitivity of simulated nitrate to the deposition velocity for nitric acid by doubling this value year-round. Figure 6 shows that particulate nitrate concentrations decrease by less than $10 \%$, and therefore that uncertainties in deposition velocities cannot reconcile the GEOS-Chem simulation with the nitrate observations at the IMPROVE sites. Alvarado et al. (2010) previously showed that nitric acid concentrations measured during the ARCTAS campaign were overestimated by over a factor of two in GEOS-Chem and invoke insufficient precipitation scavenging in the Arctic. A good simulation of the wet removal of aerosols over the continental United States (Fisher et al., 2011) in concert with the high solubility of nitric acid makes this an unlikely source of the bias here; however, uncertainties in precipitation distribution and frequency are large and we cannot rule out an underestimate of wet scavenging as a contributing factor in the nitrate bias.
Figure 6 shows that when nitric acid concentrations are artificially decreased to $75 \%$ of their values at each timestep (as an input to the thermodynamic gas-particle partitioning only), annual mean US surface nitrate concentrations can decrease by up to $2 \mu \mathrm{g} \mathrm{m}^{-3}$. This decrease brings the nitrate simulation into near agreement with the IMPROVE measurements (Fig. 7), with the exception of California, where the existing bias is exacerbated (see Sect. 4.1). Nitrate concentrations remain somewhat high in the Northeast $(\mathrm{NMB}=0.42$ for the Eastern US), particularly in winter when ammonium nitrate formation is favored. However, overall, model performance is substantially improved by this forced reduction in nitric acid with NMB values in the Eastern US considerably lower (all below 0.50) than baseline values shown in Fig. 3. Figure 8 shows how this decreased nitric acid brings the model into agreement with the ammonia, nitrate and ammonium observations from the Midwest Ammonia Monitoring Project in 2004. A reduction of nitric acid reduces ammonium nitrate formation and conversely forces more ammonia into the gas-phase, particularly in the fall and winter. Ammonium nitrate concentrations may still be overestimated in the simulation, consistent with the Fig. 6 comparison with IMPROVE sites, but overall model bias is drastically reduced. 

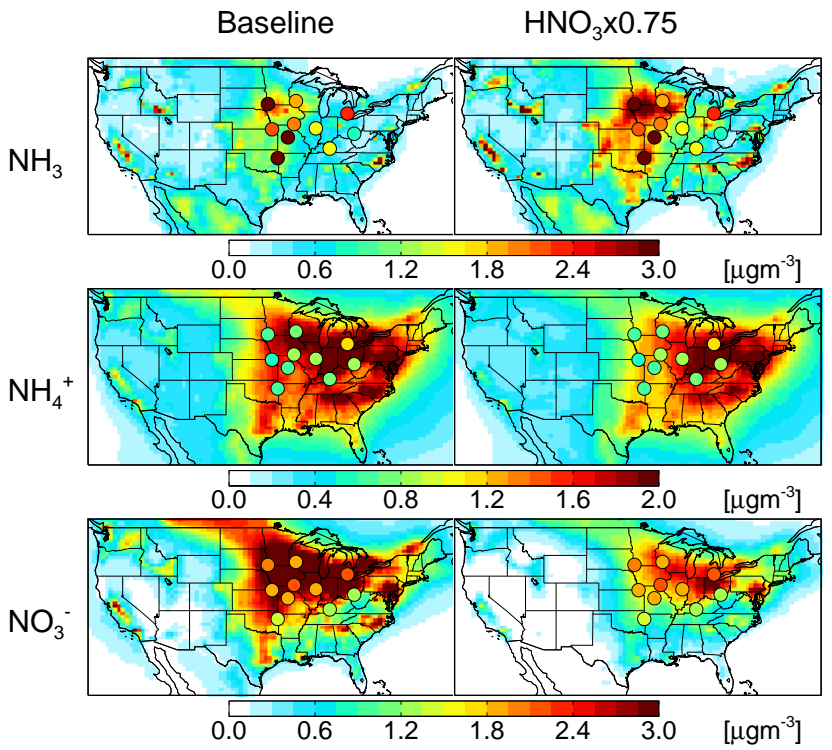

Fig. 8. Annual mean concentrations of ammonia and speciated fine ammonium nitrate during the Midwest Ammonia Monitoring Project in 2004. GEOS-Chem means (left=baseline simulation, right=updated simulation) are shown with observed means overlaid.

Figure 9 shows that this "updated" simulation with reduced nitric acid also compares well with the year-round nitrate observations in Wyoming and Colorado. Nitrate at the Loveland and Brush sites is underestimated in the wintertime with the "updated" simulation, however Fig. 5 suggests that this is associated with an underestimated wintertime supply of ammonia. Year-round cattle operations in the region likely maintain ammonia emissions in cooler seasons above the summertime-peaking seasonality currently applied to all anthropogenic ammonia emissions in the NEI-05 inventory. This calls for a dis-aggregation of ammonia emissions and an investigation of the seasonality of emissions in various sectors.

While we can identify no single process or uncertainty that could result in the current overestimation of surface nitrate concentrations in the GEOS-Chem simulation, it is clear that a simple year-round reduction of nitric acid can improve model performance drastically. A number of processes may potentially contribute to this. First, while we have tested the impact of oxidant loading and $\mathrm{N}_{2} \mathrm{O}_{5}$ hydrolysis, there may be other unrecognized chemical pathways for $\mathrm{NO}_{\mathrm{y}}$ cycling which may reduce nitric acid formation. Second, an underestimate of deposition of nitric acid could contribute to this bias, however as shown above, this cannot explain the entire model bias. Third, uptake of $\mathrm{HNO}_{3}$ on coarse $\mathrm{PM}$ (not treated here) may reduce both nitric acid and nitrate concentrations, particularly in the dusty southwest. Fourth, the vertical subgrid gradient of nitric acid at the surface may induce a similar gradient in ammonium nitrate formation which has not been accounted for here. Sievering et al. (2001) find that the

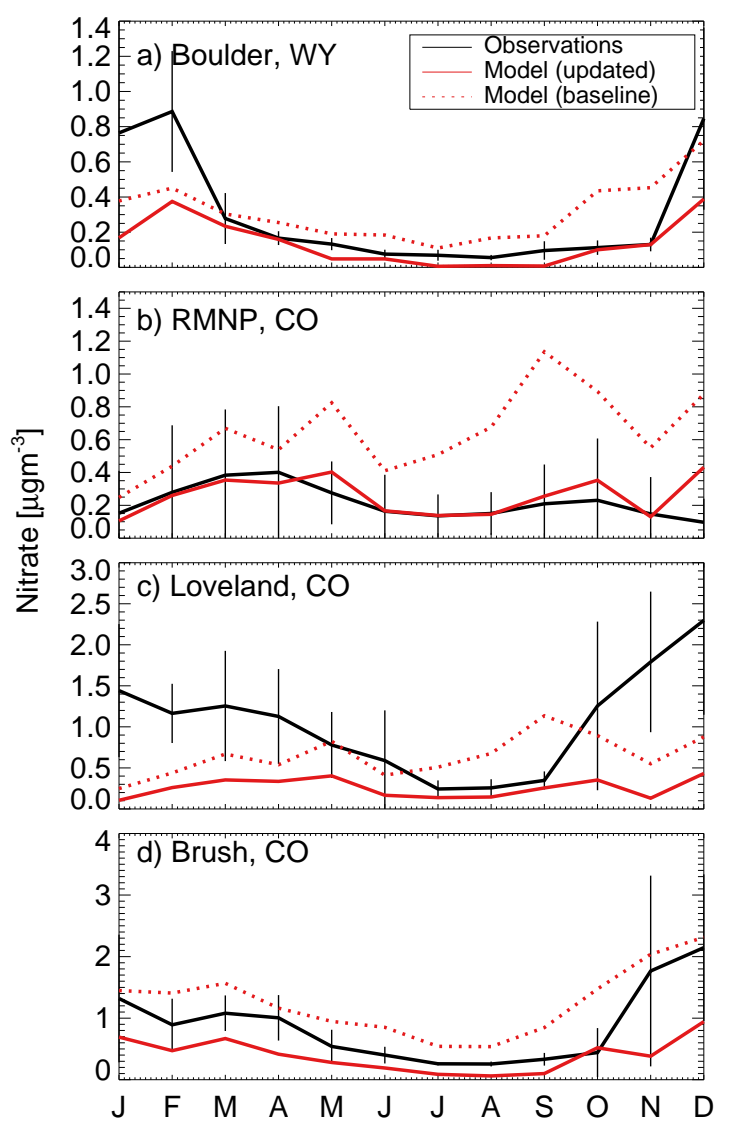

Fig. 9. Timeseries of year-long monthly mean fine nitrate concentrations measured (black) and simulated (red) in 2009 at 4 sites (from west to east): (a) Boulder, WY, (b) Rocky Mountain National Park, $\mathrm{CO}$, (c) Loveland, CO and d) Brush, CO (solid). Standard deviation of the individual observations averaged for each month shown as error bars.

vertical gradient in nitrate is weaker than for $\mathrm{HNO}_{3}$, suggesting that thermodynamic equilibrium may not be maintained through the surface layer. de Brugh et al. (2012) suggest that not accounting for this effect can mute the simulated diurnal cycle. They recommend artificially increasing the altitude of the meteorological input parameters in coarse resolution models to correct for this effect; however, they show that this correction is only valid in unstable conditions. It is unclear how this would impact the comparison of daily mean surface concentrations. Additional time-resolved gas-particle vertical profile measurements through the boundary layer are required to investigate this phenomenon further and develop an appropriate global correction for coarse resolution models such as GEOS-Chem. We note that no effort was made to optimize our artificial nitric acid reduction seasonally, and the uncertainties outlined above may play a role in different seasons, as well as different regions. 

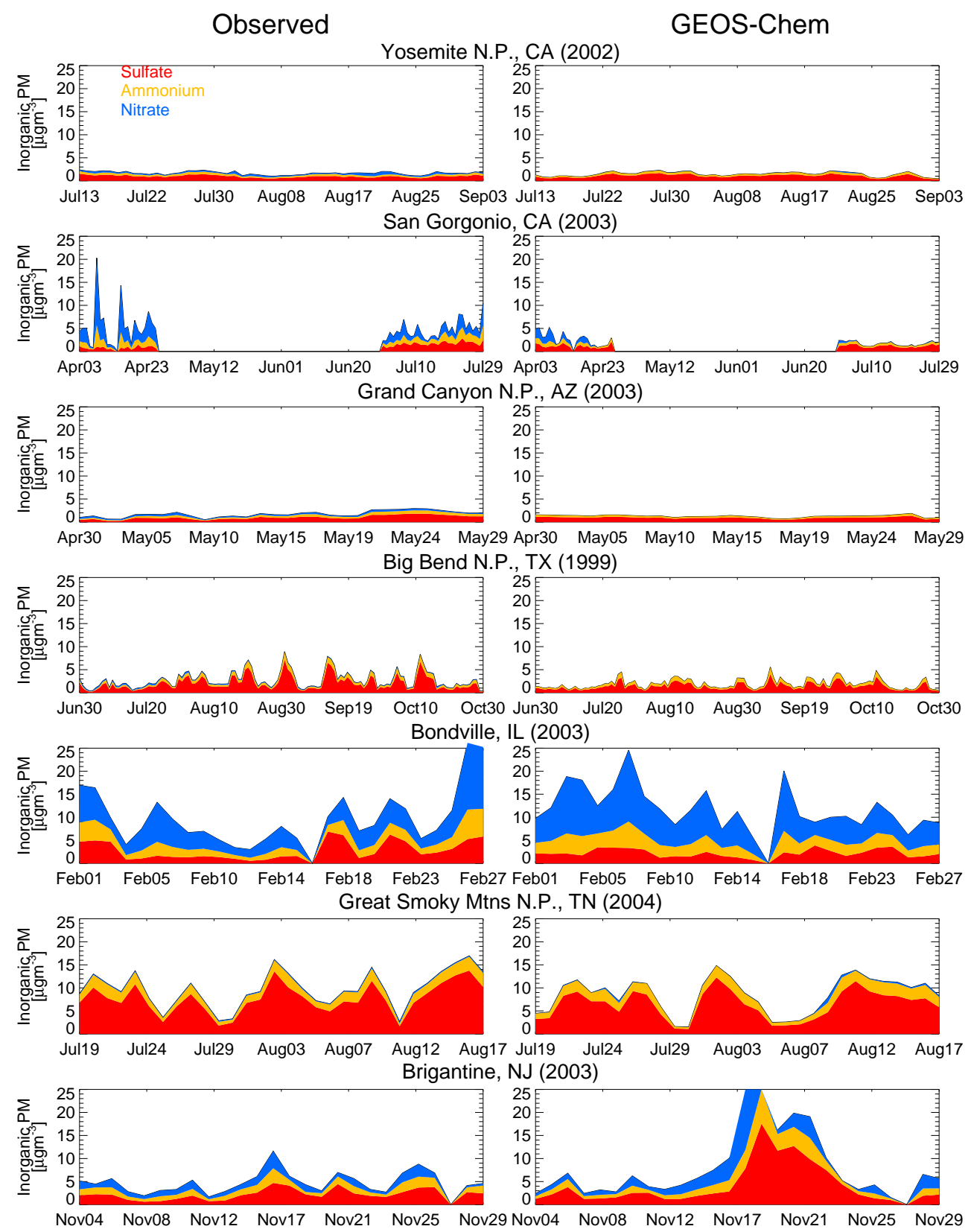

Fig. 10. Timeseries of daily mean aerosol concentrations observed (left) and simulated (right) at the 7 focus sites. GEOS-Chem simulation is for 2004, years of measurements shown with site names.

\subsection{Application of "updated" simulation}

Figure 10 compares this "updated" $\left(\mathrm{HNO}_{3}\right.$ reduced to $\left.75 \%\right)$ simulation with the daily observations of inorganic PM from the seven focus sites (Sect. 2.2) as an independent check on the comparisons discussed in Sect. 4.3. The timeseries also illustrates the regional and temporal variability of inorganic PM across the United States. Sites are ordered roughly west to east. Note that measurements do not correspond to the 2004 year of the simulation for six of the seven sites, and thus meteorological variability can degrade these compar- isons. The "updated" model simulation reproduces the character of inorganic PM across the US both in magnitude and variability. Concentrations are highest in the East and contributions from nitrate are largest in the fall/winter and in the western US. Elevated PM concentrations are episodic and generally persist for 2-3 days.

The seasonal mean simulated gas fraction for the three inorganic classes $\left(\mathrm{SO}_{\mathrm{x}}, \mathrm{NH}_{\mathrm{x}}\right.$ and total nitrate) are compared to these same observations in Fig. 11. These patterns illustrate the complex gas-particle partitioning regimes across 

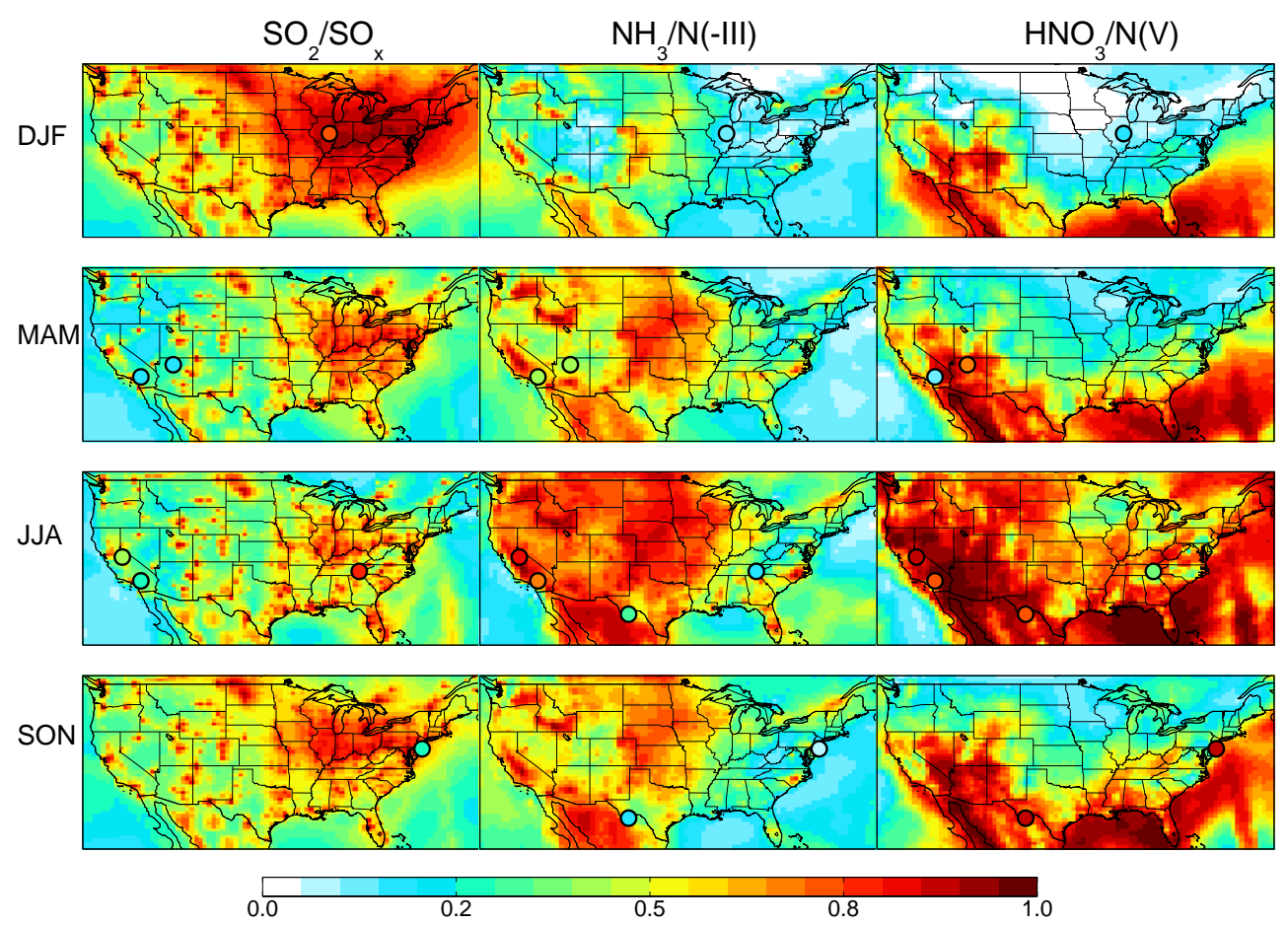

Fig. 11. Seasonal mean surface gas fractions simulated with GEOS-Chem for 2004. Mean observations (from 1999, 2002, 2003 and 2004) overlaid on corresponding season. $\mathrm{SO}_{2}$ concentrations were not measured at the Big Bend National Park site (Sect. 2.2).

the United States. This figure particularly illustrates the spatial variability in gas-particle partitioning and the necessity of using high-resolution simulations to resolve this behavior and usefully compare with in situ measurements. We see that sulfate formation is most efficient in the summertime due to higher oxidant loadings and that the short lifetime of $\mathrm{SO}_{2}$ results in gas fraction hot spots near local sources. GEOS-Chem captures this seasonal $\mathrm{SO}_{\mathrm{x}}$ partitioning across the United States, with the exception of the remote Brigantine, NJ site, which itself may experience predominantly processed emissions as sulfate, but which is located in a gridbox with fresh emissions.

Figure 11 shows that much of the ammonia in the eastern US neutralizes acidity in the region to form ammonium salts, and thus the N(-III) gas fraction is low. Important source regions in both California and the Midwest produce excess ammonia which locally remains predominantly in the gas-phase, particularly in the summertime. The model reproduces the observed N(-III) partitioning with the exception of the Big Bend site near the Texas-Mexico border. Observed concentrations of ammonia are very low at this site $\left(<0.4 \mu \mathrm{g} \mathrm{m}^{-3}\right)$, and are overestimated by the model by at least a factor of two (likely due to an underestimate in sulfate, Fig. 10). Given the low PM concentrations at the site, this significantly degrades the gas fraction comparison.

Much of the nitric acid in the Eastern US participates in ammonium nitrate formation given the up-wind source of ammonia from the Midwest. Conversely, much of the West-

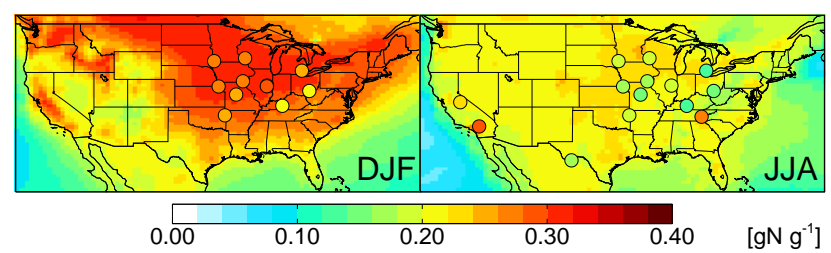

Fig. 12. Fraction of nitrogen in winter (left) and summer (right) mean surface inorganic PM mass simulated with GEOS-Chem for 2004. Mean observations both from focus sites (from 1999, 2002, 2003 and 2004) and 2004 MWNH3 campaign overlaid on corresponding season.

ern US is limited by the ammonia supply. This East-West gradient in the $\mathrm{N}(\mathrm{V})$ gas fraction is reproduced by the model, with the exception of the San Gorgonio site in California in springtime, where both complex terrain unresolved by the model, and the ammonia underestimate discussed in Sect. 4.2 and seen in Fig. 4 likely play a role. We note that using surface measurements to evaluate the simulation of total nitrate partitioning presumes that any near-surface gradient is consistent between nitric acid and nitrate.

Figure 12 quantifies the nitrogen contribution to inorganic PM mass. In particular we see that in wintertime nitrogen makes up over a third of inorganic PM mass in the Northern United States. In all seasons at least $15 \%$ of continental inorganic PM mass is nitrogen, and this fraction will almost 
certainly grow as drastic further reductions in sulfur emissions expected in the United States (van Vuuren et al., 2011) are likely to outpace the recent decline in $\mathrm{NO}_{\mathrm{x}}$ emissions (Pinder et al., 2011). Furthermore, organic nitrogen may contribute significant additional nitrogen mass to total fine PM (Fry et al., 2009; Rollins et al., 2009).

\section{Conclusions}

Model simulations of inorganic PM are typically evaluated by network measurements of sulfate and nitrate concentrations or wet deposition. Comparison of a 2004 GEOS-Chem simulation with observations of sulfate and nitrate at IMPROVE sites reveals the following features: (1) a good simulation of sulfate concentrations year-round with a modest high bias in the Northeast in the Fall and a modest underestimate in the Southeast in the summer; (2) an underestimate of nitrate concentrations year-round in California and (3) a large positive bias in nitrate year-round across the rest of the United States, likely associated with an overestimate in nitric acid concentrations previously reported by Zhang et al. (2012). IASI observations confirm that ammonia concentrations are underestimated in California and are likely the source of the nitrate underestimate in this region. A recent, independent study by Walker et al. (2012) reaches the same conclusion. A spatially diverse set of full year observations is required in the region to further characterize the emission discrepancies. Comparison with IASI also suggests that ammonia concentrations are underestimated in the springtime with current assumed emission seasonality, however increasing emissions in this region only exacerbates the nitrate bias.

We explore the sensitivity of simulated nitrate to a number of uncertain model parameters related both to chemistry and deposition but are unable to identify the cause of the model overestimate. We do find that decreasing nitric acid concentrations uniformly to $75 \%$ of simulated values brings the model into close agreement with the IMPROVE nitrate measurements, as well as the ammonium and nitrate measured during the Midwest Ammonia Monitoring Project and the year-round nitrate measured at a suite of sites in Wyoming and Colorado. Further investigation into the role of sub-grid near-surface processes and the nitric acid budget are required to resolve this. In particular, tower-based measurements of the boundary layer vertical profile and fluxes could provide critical insight into this question. Further investigation of the importance of coarse mode nitrate as a control on nitric acid concentrations and fine particle nitrate throughout the US is also required.

We demonstrate the challenges of reproducing strong ammonia gradients near source regions. However we also show that the impact of underestimating ammonia near these sources on PM formation is limited, at least in the near-field. The fate of this excess ammonia and the prevalence of these underrepresented "hot spot" emissions in the United States requires further investigation in order to accurately characterize local deposition and ecosystem response. Furthermore, our full year comparisons for sites in Wyoming and Colorado suggest that fertilizer and livestock ammonia emissions may exhibit quite different seasonality with implications for ammonium nitrate formation in wintertime.

This study uses a suite of in situ and satellite measurements, in particular focusing on ammonia, to evaluate our understanding of the inorganic gas-particle system. While we provide examples of model skill, the complexity of this system remains a challenge to capture with full fidelity. For example, inclusion of bi-directional treatment of ammonia fluxes may improve day-to-day variability in the model and the simulation of downwind concentrations (Cooter et al., 2010). Additional co-located measurements of both gas and particle phase inorganics are required to further constrain models and refine schemes that can be applied to accurately characterize both PM formation and nitrogen deposition in the United States.

Acknowledgements. This work was supported by NOAA (NA12OAR4310064). Measurements at Big Bend NP, Yosemite NP, San Gorgonio, Bondville, Brigantine, Great Smoky Mountain NP, Rocky Mountain NP, Loveland Brush were supported by the National Park Service. Field assistance from D. Day, X. Yu, and B. Ayres is gratefully acknowledged. Measurements at Boulder, WY were supported by Shell Exploration and Development Company and taken in collaboration with Air Resource Specialists, Inc. IASI was developed and built under the responsibility of CNES and flies onboard the MetOp satellite as part of the Eumetsat Polar system. The IASI L1 data are received through the EUMETCast near real time data distribution service. LC, PFC and MVD are respectively Postdoctoral Researcher, Research Associate and FRIA grant holder with F.R.S.-FNRS. CC is grateful to CNES for scientific collaboration and financial support. The research in Belgium was funded by the BELSPO and ESA (Prodex arrangements). We acknowledge support from the ECLAIRE project (EU-FP7) and the "Actions de Recherche Concertées" (Communauté Française de Belgique). RVM and SP acknowledge support from NSERC Canada. Although this paper has been reviewed by the EPA and approved for publication, it does not necessarily reflect EPA policies or views.

Edited by: J. G. Murphy

\section{References}

Aan de Brugh, J. M. J., Henzing, J. S., Schaap, M., Morgan, W. T., van Heerwaarden, C. C., Weijers, E. P., Coe, H., and Krol, M. C.: Modelling the partitioning of ammonium nitrate in the convective boundary layer, Atmos. Chem. Phys., 12, 3005-3023, doi:10.5194/acp-12-3005-2012, 2012.

Abbatt, J. P. D., and Waschewsky, G. C. G.: Heterogeneous interactions of $\mathrm{HOBr}, \mathrm{HNO}_{3}, \mathrm{O}_{3}^{-}$, and $\mathrm{NO}_{2}$ with deliquescent $\mathrm{NaCl}$ aerosols at room temperature, J. Phys. Chem. A, 102, 37193725, doi:10.1021/jp980932d, 1998. 
Adams, P. J., Seinfeld, J. H., and Koch, D. M.: Global concentrations of tropospheric sulfate, nitrate, and ammonium aerosol simulated in a general circulation model, J. Geophys. Res.-Atmos., 104, 13791-13823, 1999.

Alvarado, M. J., Logan, J. A., Mao, J., Apel, E., Riemer, D., Blake, D., Cohen, R. C., Min, K. E., Perring, A. E., Browne, E. C., Wooldridge, P. J., Diskin, G. S., Sachse, G. W., Fuelberg, H., Sessions, W. R., Harrigan, D. L., Huey, G., Liao, J., Case-Hanks, A., Jimenez, J. L., Cubison, M. J., Vay, S. A., Weinheimer, A. J., Knapp, D. J., Montzka, D. D., Flocke, F. M., Pollack, I. B., Wennberg, P. O., Kurten, A., Crounse, J., St. Clair, J. M., Wisthaler, A., Mikoviny, T., Yantosca, R. M., Carouge, C. C., and Le Sager, P.: Nitrogen oxides and PAN in plumes from boreal fires during ARCTAS-B and their impact on ozone: an integrated analysis of aircraft and satellite observations, Atmos. Chem. Phys., 10, 9739-9760, doi:10.5194/acp-10-9739-2010, 2010.

Ames, R. B. and Malm, W. C.: Comparison of sulfate and nitrate particle mass concentrations measured by IMPROVE and the CDN, Atmos. Environ., 35, 905-916, 2001.

Beem, K. B., Raja, S., Schwandner, F. M., Taylor, C., Lee, T., Sullivan, A. P., Carrico, C. M., McMeeking, G. R., Day, D., Levin, E., Hand, J., Kreidenweis, S. M., Schichtel, B., Malm, W. C., and Collett, J. L.: Deposition of reactive nitrogen during the Rocky Mountain Airborne Nitrogen and Sulfur (RoMANS) study, Environ. Pollut., 158, 862-872, doi:10.1016/j.envpol.2009.09.023, 2010.

Beer, R., Shephard, M. W., Kulawik, S. S., Clough, S. A., Eldering, A., Bowman, K. W., Sander, S. P., Fisher, B. M., Payne, V. H., Luo, M. Z., Osterman, G. B., and Worden, J. R.: First satellite observations of lower tropospheric ammonia and methanol, Geophys. Res. Lett., 35, L09801, doi:10.1029/2008g1033642, 2008.

Bessagnet, B., Hodzic, A., Vautard, R., Beekmann, M., Cheinet, S., Honore, C., Liousse, C., and Rouil, L.: Aerosol modeling with CHIMERE - preliminary evaluation at the continental scale, Atmos. Environ., 38, 2803-2817, doi:10.1016/j.atmosenv.2004.02.034, 2004.

Blanchard, C. L. and Tanenbaum, S.: Draft Final Technical Memorandum: Analysis of Data from the Midwest Ammonia Monitoring Project, Envair, Albany, CA, USA, 2005.

Bouwman, A. F., Lee, D. S., Asman, W. A. H., Dentener, F. J., Vander Hoek, K. W., and Olivier, J. G. J.: A global high-resolution emission inventory for ammonia, Glob. Biogeochem. Cy., 11, 561-587, 1997.

Chen, D., Wang, Y., McElroy, M. B., He, K., Yantosca, R. M., and Le Sager, P.: Regional CO pollution in China simulated by the high-resolution nested-grid GEOS-Chem model, Atmos. Chem. Phys. Discuss., 9, 5853-5887, doi:10.5194/acpd-9-5853-2009, 2009.

Chow, J. C., Watson, J. G., Lu, Z. Q., Lowenthal, D. H., Frazier, C. A., Solomon, P. A., Thuillier, R. H., and Magliano, K.: Descriptive analysis of $\mathrm{PM}(2.5)$ and $\mathrm{PM}(10)$ at regionally representative locations during SJVAQS/AUSPEX, Atmos. Environ., 30, 20792112, 1996.

Clarisse, L., Clerbaux, C., Dentener, F., Hurtmans, D., and Coheur, P. F.: Global ammonia distribution derived from infrared satellite observations, Nature Geosci., 2, 479-483, doi:10.1038/ngeo551, 2009.

Clarisse, L., Shephard, M. W., Dentener, F., Hurtmans, D., CadyPereira, K., Karagulian, F., Van Damme, M., Clerbaux, C., and
Coheur, P. F.: Satellite monitoring of ammonia: A case study of the San Joaquin Valley, J. Geophys. Res.-Atmos., 115, D13302, doi:10.1029/2009jd013291, 2010.

Clarke, J. F., Edgerton, E. S., and Martin, B. E.: Dry Deposition Calculations for the Clean Air Status and Trends Network, Atmos. Environ., 31, 3367-3678, 1997.

Clerbaux, C., Boynard, A., Clarisse, L., George, M., Hadji-Lazaro, J., Herbin, H., Hurtmans, D., Pommier, M., Razavi, A., Turquety, S., Wespes, C., and Coheur, P.-F.: Monitoring of atmospheric composition using the thermal infrared IASI/MetOp sounder, Atmos. Chem. Phys., 9, 6041-6054, doi:10.5194/acp-9-6041-2009, 2009.

Cooter, E. J., Bash, J. O., Walker, J. T., Jones, M. R., and Robarge, W.: Estimation of $\mathrm{NH} 3$ bi-directional flux from managed agricultural soils, Atmos. Environ., 44, 2107-2115, doi:10.1016/j.atmosenv.2010.02.044, 2010.

Crouse, D. L., Peters, P. A., van Donkelaar, A., Goldberg, M. S., Villeneuve, P. J., Brion, O., Khan, S., Atari, D. O., Jerrett, M., Pope, C. A., Brauer, M., Brook, J. R., Martin, R. V., Stieb, D., and Burnett, R. T.: Risk of Non accidental and Cardiovascular Mortality in Relation to Long-term Exposure to Low Concentrations of Fine Particulate Matter: A Canadian NationalLevel Cohort Study, Environ. Health Perspect., 120, 708-714, doi:10.1289/ehp.1104049, 2012.

Dockery, D. W., Pope, C. A., Xu, X. P., Spengler, J. D., Ware, J. H., Fay, M. E., Ferris, B. G., and Speizer, F. E.: An association between air-pollution and mortality in 6 United-States cities, $\mathrm{N}$. Engl. J. Med., 329, 1753-1759, 1993.

Ellis, R. A., Murphy, J. G., Markovic, M. Z., VandenBoer, T. C., Makar, P. A., Brook, J., and Mihele, C.: The influence of gasparticle partitioning and surface-atmosphere exchange on ammonia during BAQS-Met, Atmos. Chem. Phys., 11, 133-145, doi:10.5194/acp-11-133-2011, 2011.

Erisman, J. W., Sutton, M. A., Galloway, J., Klimont, Z., and Winiwater, W.: How a century of ammonia synthesis changed the world, Nature Geosci., 1, 636-639, doi:10.1038/ngeo325, 2008.

Fairlie, T. D., Jacob, D. J., Dibb, J. E., Alexander, B., Avery, M. A., van Donkelaar, A., and Zhang, L.: Impact of mineral dust on nitrate, sulfate, and ozone in transpacific Asian pollution plumes, Atmos. Chem. Phys., 10, 3999-4012, doi:10.5194/acp-10-39992010, 2010.

Fisher, J. A., Jacob, D. J., Wang, Q., Bahreini, R., Carouge, C. C., Cubison, M. J., Dibb, J. E., Diehl, T., Jimenez, J. L., Leibensperger, E. M., Meinders, M. B. J., Pye, H. O. T., Quinn, P. K., Sharma, S., van Donkelaar, A., and Yantosca, R. M.: Sources, distribution, and acidity of sulfate-ammonium aerosol in the Arctic in winter-spring, Atmos. Environ., 45, 7301-7318, 2011.

Fountoukis, C., and Nenes, A.: ISORROPIA II: a computationally efficient thermodynamic equilibrium model for $\mathrm{K}^{+}$$\mathrm{Ca}^{2+}-\mathrm{Mg}^{2+}-\mathrm{NH}_{4}^{+}-\mathrm{Na}^{+}-\mathrm{SO}_{4}^{2-}-\mathrm{NO}_{3}^{-}-\mathrm{Cl}^{-}-\mathrm{H}_{2} \mathrm{O}$ aerosols, Atmos. Chem. Phys., 7, 4639-4659, doi:10.5194/acp-7-4639-2007, 2007.

Fry, J. L., Kiendler-Scharr, A., Rollins, A. W., Wooldridge, P. J., Brown, S. S., Fuchs, H., Dube, W. P., Mensah, A., dal Maso, M., Tillmann, R., Dorn, H.-P., Brauers, T., and Cohen, R. C.: Organic nitrate and secondary organic aerosol yield from $\mathrm{NO}_{3}$ oxidation of beta-pinene evaluated using a gas-phase kinetics/aerosol partitioning model, Atmos. Chem. Phys., 9, 14311449, doi:10.5194/acp-9-1431-2009, 2009. 
Gilliland, A. B., Appel, K. W., Pinder, R. W., and Dennis, R. L.: Seasonal NH3 emissions for the continental united states: Inverse model estimation and evaluation, ISI:000240175300015, 49864998, 2006.

Goebes, M. D., Strader, R., and Davidson, C.: An ammonia emission inventory for fertilizer application in the United States, Atmos. Environ., 37, 2539-2550, doi:10.1016/s13522310(03)00129-8, 2003.

Goodman, A. L., Underwood, G. M., and Grassian, V. H.: A laboratory study of the heterogeneous reaction of nitric acid on calcium carbonate particles, J. Geophys. Res.-Atmos., 105, 2905329064, doi:10.1029/2000jd900396, 2000.

Guenther, A. B., Jiang, X., Heald, C. L., Sakulyanontvittaya, T., Duhl, T., Emmons, L. K., and Wang, X.: The Model of Emissions of Gases and Aerosols from Nature version 2.1 (MEGAN 2.1): an extended and updated framework for modeling biogenic emissions, Geoscientific Model Development Discussions, 5, 15031560, doi:10.5194/gmdd-5-1503-2012, 2012.

Henderson, B. H., Pinder, R. W., Crooks, J., Cohen, R. C., Carlton, A. G., Pye, H. O. T., and Vizuete, W.: Combining Bayesian methods and aircraft observations to constrain the HO center dot $+\mathrm{NO}_{2}$ reaction rate, Atmos. Chem. Phys., 12, 653-667, doi:10.5194/acp-12-653-2012, 2012.

Henze, D. K., Seinfeld, J. H., and Shindell, D. T.: Inverse modeling and mapping US air quality influences of inorganic $\mathrm{PM}_{2.5}$ precursor emissions using the adjoint of GEOS-Chem, Atmos. Chem. Phys., 9, 5877-5903, doi:10.5194/acp-9-5877-2009, 2009.

Hristov, A. N., Hanigan, M., Cole, A., Todd, R., McAllister, T. A., Ndegwa, P. M., and Rotz, A.: Review: Ammonia emissions from dairy farms and beef feedlots, Can. J. Anim. Sci., 91, 1-35, doi:10.4141/cjas10034, 2011.

Hurtmans, D., Coheur, P.-F., Wespes, C., Clarisse, L., Scarf, O., Clerbaux, C., Hadji-Lazaro, J., George, M., and Turquety, S.: FORLI radiative transfer and retrieval code for IASI, J. Quanti. Spectros. Radiat. Transfer, 113, 1391-1408, 2012.

Koracin, D., and Berkowicz, R.: Nocturnal boundary-layer height - observations by acoustic sounders and predictions in terms of surface-layer parameters, Bound.-Layer Meteorol., 43, 65-83, doi:10.1007/bf00153969, 1988.

Lamsal, L. N., Martin, R. V., Padmanabhan, A., van Donkelaar, A., Zhang, Q., Sioris, C. E., Chance, K., Kurosu, T. P., and Newchurch, M. J.: Application of satellite observations for timely updates to global anthropogenic $\mathrm{NO}_{(\mathrm{x})}$ emission inventories, Geophys. Res. Lett., 38, L05810, doi:10.1029/2010g1046476, 2011.

Lee, T., Kreidenweis, S. M., and Collett Jr., J. L.: Aerosol Ion Characteristics during the Big Bend Regional Aerosol and Visibility Observational Study, J. Air Waste Manage. Assoc., 54, 585-592, 2004.

Lee, T., Yu, X.-Y., Ayres, B., Kreidenweis, S. M., Malm, W. C., and Collett Jr., J. L.: Observation of fine and coarse particle nitrate at several rural locations in the United States, Atmos. Environ., 42, 2720-2732, 2008a.

Lee, T., Yu, X. Y., Kreidenweis, S. M., Malm, W. C., and Collett, J. L.: Semi-continuous measurement of PM2.5 ionic composition at several rural locations in the United States, Atmos. Environ., 42, 6655-6669, doi:10.1016/j.atmosenv.2008.04.023, 2008b.
Lin, J. T. and McElroy, M. B.: Impacts of boundary layer mixing on pollutant vertical profiles in the lower troposphere: Implications to satellite remote sensing, Atmos. Environ., 44, 17261739, doi:10.1016/j.atmosenv.2010.02.009, 2010.

Liu, H. Y., Jacob, D. J., Bey, I., and Yantosca, R. M.: Constraints from $\mathrm{Pb}-210$ and $\mathrm{Be}-7$ on wet deposition and transport in a global three-dimensional chemical tracer model driven by assimilated meteorological fields, J. Geophys. Res.-Atmos., 106, 12109-12128, 2001.

Liu, S. Y. and Liang, X. Z.: Observed Diurnal Cycle Climatology of Planetary Boundary Layer Height, J. Climate, 23, 5790-5809, doi:10.1175/2010jcli3552.1, 2010.

Makar, P. A., Moran, M. D., Zheng, Q., Cousineau, S., Sassi, M., Duhamel, A., Besner, M., Davignon, D., Crevier, L. P., and Bouchet, V. S.: Modelling the impacts of ammonia emissions reductions on North American air quality, Atmos. Chem. Phys., 9, 7183-7212, doi:10.5194/acp-9-7183-2009, 2009.

Malm, W. C., Sisler, J. F., Huffman, D., Eldred, R. A., and Cahill, T. A.: Spatial and seasonal trends in particle concentration and optical extinction in the United States, J. Geophys. Res.-Atmos., 99, 1347-1370, 1994.

Malm, W. C., Schichtel, B. A., Pitchford, M. L., Ashbaugh, L. L., and Eldred, R. A.: Spatial and monthly trends in speciated fine particle concentration in the United States, J. Geophys. Res.Atmos., 109, D03306, doi:10.1029/2003jd003739, 2004.

Martin, R. V., Sioris, C. E., Chance, K., Ryerson, T. B., Bertram, T. H., Wooldridge, P. J., Cohen, R. C., Neuman, J. A., Swanson, A., and Flocke, F. M.: Evaluation of space-based constraints on global nitrogen oxide emissions with regional aircraft measurements over and downwind of eastern North America, J. Geophys. Res.-Atmos., 111, D15308, doi:10.1029/2005jd006680, 2006.

McIntyre, H. L. and Evans, M. J.: Sensitivity of a global model to the uptake of $\mathrm{N}_{2} \mathrm{O}_{5}$ by tropospheric aerosol, Atmos. Chem. Phys., 10, 7409-7414, doi:10.5194/acp-10-7409-2010, 2010.

Mollner, A. K., Valluvadasan, S., Feng, L., Sprague, M. K., Okumura, M., Milligan, D. B., Bloss, W. J., Sander, S. P., Martien, P. T., Harley, R. A., McCoy, A. B., and Carter, W. P. L.: Rate of Gas Phase Association of Hydroxyl Radical and Nitrogen Dioxide, Science, 330, 646-649, doi:10.1126/science.1193030, 2010.

NARSTO: Particulate Matter Science for Policy Makers: A NARSTO Assessment, Cambridge, UK, 2004.

Nowak, J. B., Huey, L. G., Russell, A. G., Tian, D., Neuman, J. A., Orsini, D., Sjostedt, S. J., Sullivan, A. P., Tanner, D. J., Weber, R. J., Nenes, A., Edgerton, E., and Fehsenfeld, F. C.: Analysis of urban gas phase ammonia measurements from the 2002 Atlanta Aerosol Nucleation and Real-Time Characterization Experiment (ANARChE), J. Geophys. Res.-Atmos., 111, D17308, doi:10.1029/2006jd007113, 2006.

Nowak, J. B., Neuman, A. J., Bahreini, R., Brock, C. A., Middlebrook, A. M., Wollny, A. G., Holloway, J. S., Peischl, J., Ryerson, T. B., and Fehsenfeld, F. C.: Airborne observations of ammonia and ammonium nitrate formation over Houston, TX, J. Geophys Res., 115, D22304, doi:10.1029/2010JD014195, 2010.

Nowak, J. B., Neuman, J. A., Bahreini, R., Middlebrook, A. M., Holloway, J. S., McKeen, S. A., Parish, D. D., Ryerson, T. B., and Trainer, M.: Ammonia sources in the California South Coast Air Bain and their impact on ammonium nitrate formation, Geophys. Res. Lett., 39, L07804, doi:10.1029/2012GL051197, 2012. 
Park, R. J., Jacob, D. J., Field, B. D., Yantosca, R. M., and Chin, M.: Natural and transboundary pollution influences on sulfate-nitrate-ammonium aerosols in the United States: Implications for policy, J. Geophys. Res.-Atmos., 109, D15204, doi:10.1029/2003JD004473, 2004.

Pinder, R. W., Adams, P. J., Pandis, S. N., and Gilliland, A. B.: Temporally resolved ammonia emission inventories: Current estimates, evaluation tools, and measurement needs, J. Geophys. Res.-Atmos., 111, D16310, doi:10.1029/2005jd006603, 2006.

Pinder, R. W., Adams, P. J., and Pandis, S. N.: Ammonia emission controls as a cost-effective strategy for reducing atmospheric particulate matter in the eastern United States, Environ. Sci. Technol., 41, 380-386, doi:10.1021/es060379a, 2007.

Pinder, R. W., Gilliland, A. B., and Dennis, R. L.: Environmental impact of atmospheric NH3 emissions under present and future conditions in the eastern United States, Geophys. Res. Lett., 35, 6, L12808, doi:10.1029/2008g1033732, 2008.

Pinder, R. W., Appel, K. W., and Dennis, R. L.: Trends in atmospheric reactive nitrogen for the Eastern United States, Environ. Pollut., 159, 3138-3141, doi:10.1016/j.envpol.2011.04.042, 2011.

Pope, C. A., Ezzati, M., and Dockery, D. W.: Fine-Particulate Air Pollution and Life Expectancy in the United States, N. Engl. J. Med., 360, 376-386, 2009.

Pye, H. O. T., Liao, H., Wu, S., Mickley, L. J., Jacob, D. J., Henze, D. K., and Seinfeld, J. H.: Effect of changes in climate and emissions on future sulfate-nitrate-ammonium aerosol levels in the United States, J. Geophys. Res.-Atmos., 114, 18, D01205, doi:10.1029/2008jd010701, 2009.

Rodgers, C. D.: Inverse Methods for Atmospheric Sounding: Theory and Practice, World Scientific Publishing Co., Singapore, 238 pp., 2000.

Rollins, A. W., Kiendler-Scharr, A., Fry, J. L., Brauers, T., Brown, S. S., Dorn, H.-P., Dube, W. P., Fuchs, H., Mensah, A., Mentel, T. F., Rohrer, F., Tillmann, R., WEgener, R., Wooldridge, P. J., and Cohen, R. C.: Isoprene oxidation by nitrate radical: alkyl nitrate and secondary organic aerosol yields, Atmos. Chem. Phys., 9, 6685-6703, doi:10.5194/acp-9-6685-2009, 2009.

Schwede, D., Zhang, L. M., Vet, R., and Lear, G.: An intercomparison of the deposition models used in the CASTNET and CAPMoN networks, Atmos. Environ., 45, 1337-1346, doi:10.1016/j.atmosenv.2010.11.050, 2011.

Shephard, M. W., Cady-Pereira, K. E., Luo, M., Henze, D. K., Pinder, R. W., Walker, J. T., Rinsland, C. P., Bash, J. O., Zhu, L., Payne, V. H., and Clarisse, L.: TES ammonia retrieval strategy and global observations of the spatial and seasonal variability of ammonia Atmos. Chem. Phys., 11, 10743-10763, doi:10.5194/acp-11-10743-2011, 2011.

Sievering, H., Kelly, T., McConville, G., Seibold, C., and Turpinseed, A.: Nitric acid dry deposition to conifer forests: Niwot Ridge spruce-fir-pine study, Atmos. Environ., 35, 3851-3859, 2001.

Sweet, C., Caughey, M., and Gay, D.: Midwest Ammonia Monitoring Project: Summary for October 2003 through November 2004, Illinois State Water Survey, Champaign, IL, USA, 47, 2005.

van der Werf, G. R., Randerson, J. T., Giglio, L., Collatz, G. J., Kasibhatla, P. S., and Arellano, A. F.: Interannual variability in global biomass burning emissions from 1997 to 2004, Atmos. Chem. Phys., 6, 3423-3441, doi:10.5194/acp-6-3423-2006,
2006.

van Donkelaar, A., Martin, R. V., Leaitch, W. R., Macdonald, A. M., Walker, T. W., Streets, D. G., Zhang, Q., Dunlea, E. J., Jimenez, J. L., Dibb, J. E., Huey, L. G., Weber, R., and Andreae, M. O.: Analysis of aircraft and satellite measurements from the Intercontinental Chemical Transport Experiment (INTEX-B) to quantify long-range transport of East Asian sulfur to Canada, Atmos. Chem. Phys., 8, 2999-3014, doi:10.5194/acp-8-2999-2008, 2008.

van Vuuren, D. P., Edmonds, J., Kainuma, M., Riahi, K., Thomson, A., Hibbard, K., Hurtt, G. C., Kram, T., Krey, V., Lamarque, J. F., Masui, T., Meinshausen, M., Nakicenovic, N., Smith, S. J., and Rose, S. K.: The representative concentration pathways: an overview, Clim. Change, 109, 5-31, doi:10.1007/s10584-0110148-z, 2011.

von Bobrutzki, K., Braban, C. F., Famulari, D., Jones, S. K., Blackall, T., Smith, T. E. L., Blom, M., Coe, H., Gallagher, M., Ghalaieny, M., McGillen, M. R., Percival, C. J., Whitehead, J. D., Ellis, R., Murphy, J., Mohacsi, A., Pogany, A., Junninen, H., Rantanen, S., Sutton, M. A., and Nemitz, E.: Field inter-comparison of eleven atmospheric ammonia measurement techniques, Atmos. Meas. Tech., 3, 91-112, doi:10.5194/amt-3-91-2010, 2010.

Walker, J. M., Seinfeld, J. H., Clarisse, L., Coheur, P.-F., Clerbaux, C., and Van Damme, M.: Simulation of nitrate, sulfate, and ammonium aerosols over the United States, Atmos. Chem. Phys. Discuss., 12, 19499-19527, doi:10.5194/acpd-12-194992012, 2012.

Wang, J., Hoffmann, A. A., Park, R. J., Jacob, D. J., and Martin, S. T.: Global distribution of solid and aqueous sulfate aerosols: Effect of the hysteresis of particle phase transitions, J. Geophys. Res.-Atmos., 113, D11206, doi:10.1029/2007jd009367, 2008.

Watson, J. G., Chow, J. C., Bowen, J. L., Lowenthal, D. H., Hering, S., Ouchida, P., and Oslund, W.: Air quality measurements from the Fresno Supersite, J. Air Waste Manage. Assoc., 50, 13211334, 2000.

Wells, K. C., Millet, D. B., Hu, L., Cady-Pereira, K. E., Xiao, Y., Shephard, M. W., Clerbaux, C. L., Clarisse, L., Coheur, P.F., Apel, E. C., de Gouw, J., Warneke, C., Singh, H. B., Goldstein, A. H., and Sive, B. C.: Tropospheric methanol observations from space: retrieval evaluation and constraints on the seasonality of biogenic emissions, Atmos. Chem. Phys., 12, 5897-5912, doi:10.5194/acp-12-5897-2012, 2012.

Wesely, M. L.: Parameterization of surface resistances to gaseous dry deposition in regional scale numerical models, Atmos. Environ., 23, 1293-1304, 1989.

Yu, S. C., Dennis, R., Roselle, S., Nenes, A., Walker, J., Eder, B., Schere, K., Swall, J., and Robarge, W.: An assessment of the ability of three-dimensional air quality models with current thermodynamic equilibrium models to predict aerosol NO3, J. Geophys. Res.-Atmos., 110, 25, D07S13, doi:10.1029/2004jd004718, 2005a.

Yu, X.-Y., Lee, T., Ayres, B., Kreidenweis, S. M., and Collett Jr., J. L.: Particulate nitrate measurement using nylon filters, J. Air Waste Manage. Assoc., 55, 1100-1110, 2005b.

Yu, X. Y., Lee, T., Ayres, B., Kreidenweis, S. M., Malm, W., and Collett, J. L.: Loss of fine particle ammonium from denuded nylon filters, Atmos. Environ., 40, 4797-4807, doi:10.1016/j.atmosenv.2006.03.061, 2006. 
Zhang, L., Jacob, D. J., Knipping, E. M., Kumar, N., Munger, J. W., Carouge, C. C., van Donkelaar, A., Wang, Y. X., and Chen, D.: Nitrogen deposition to the United States: distribution, sources and processes, Atmos. Chem. Phys., 12, 4539-4554, doi:10.5194/acp-12-4539-2012, 2012. 